Prepared in cooperation with the U.S. Environmental Protection Agency

\title{
Simulation of Nitrogen Attenuation in a Subterranean Estuary, Representative of the Southern Coast of Cape Cod, Massachusetts
}

Open-File Report 2015-1085

U.S. Department of the Interior

U.S. Geological Survey 



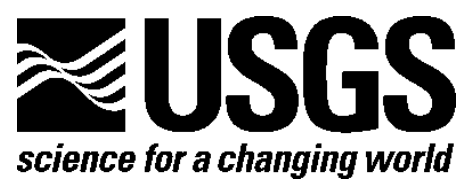

Prepared in cooperation with the U.S. Environmental Protection Agency

\section{Simulation of Nitrogen Attenuation in a Subterranean Estuary, Representative of the Southern Coast of Cape Cod, Massachusetts}

By John A. Colman, Carl S. Carlson, and Clare Robinson

Open-File Report 2015-1085

U.S. Department of the Interior

U.S. Geological Survey 


\section{U.S. Department of the Interior \\ SALLY JEWELL, Secretary}

\section{U.S. Geological Survey \\ Suzette M. Kimball, Acting Director}

U.S. Geological Survey, Reston, Virginia: 2015

For more information on the USGS—-the Federal source for science about the Earth, its natural and living resources, natural hazards, and the environment-visit http://www.usgs.gov/ or call 1-888-ASK-USGS (1-888-275-8747).

For an overview of USGS information products, including maps, imagery, and publications, visit http://www.usgs.gov/pubprod/.

Any use of trade, firm, or product names is for descriptive purposes only and does not imply endorsement by the U.S. Government.

Although this information product, for the most part, is in the public domain, it also may contain copyrighted materials as noted in the text. Permission to reproduce copyrighted items must be secured from the copyright owner.

Suggested citation:

Colman, J.A., Carlson, C.S, and Robinson, Clare, 2015, Simulation of nitrogen attenuation in a subterranean estuary, representative of the southern coast of Cape Cod, Massachusetts:

U.S. Geological Survey Open-File Report 2015-1085, 30 p., http://dx.doi.org/10.3133/ofr20151085.

ISSN 2331-1258 (online) 


\section{Contents}

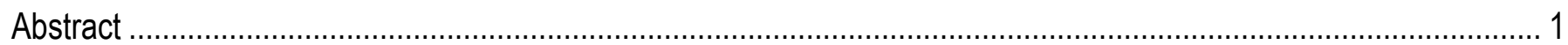

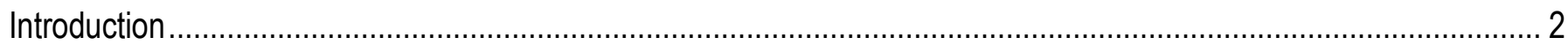

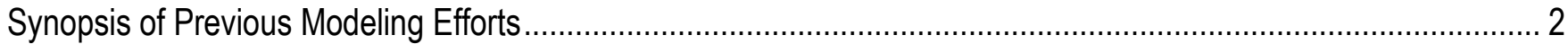

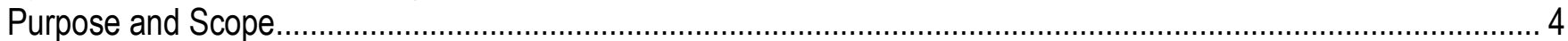

Sources and Quality of Model Data ......................................................................................................... 4

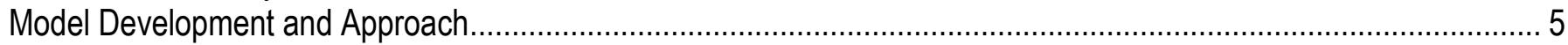

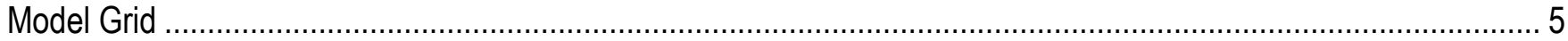

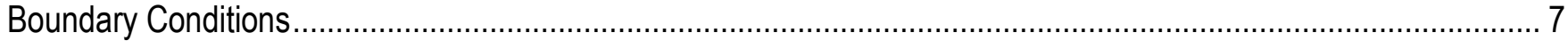

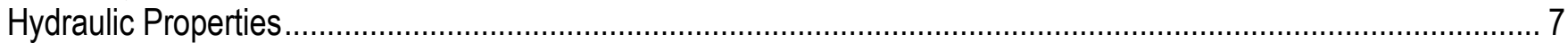

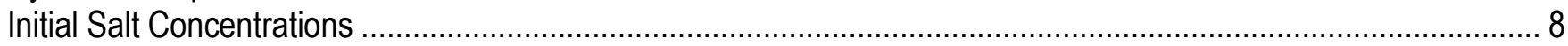

Simulation of Long-Term Mean-Tide Conditions .................................................................................... 9

Sensitivity Analysis of the Effect of Initial Salt Concentration Distributions on the Final Distribution......................... 9

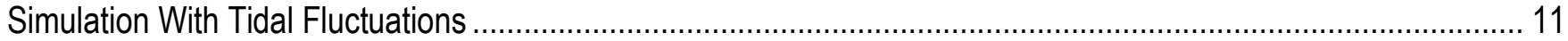

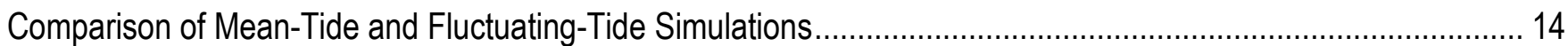

Simulation of Nitrogen Attenuation With a Model of Reactive-Solute Transport ..................................................... 14

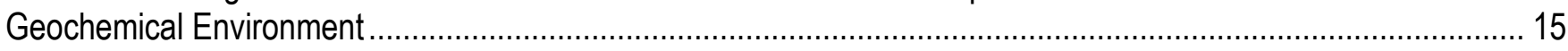

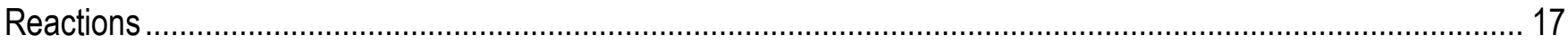

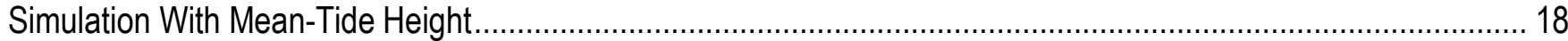

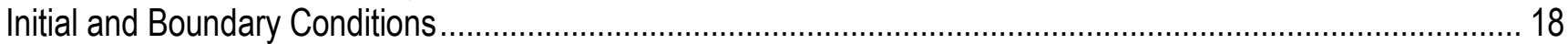

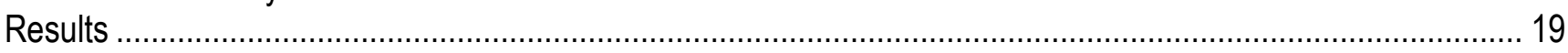

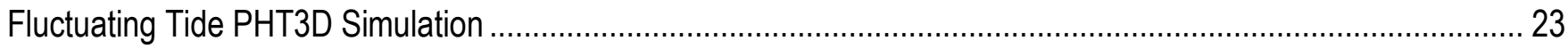

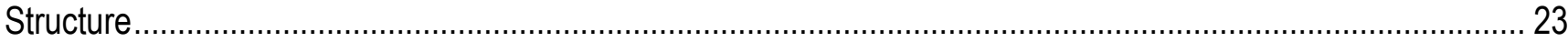

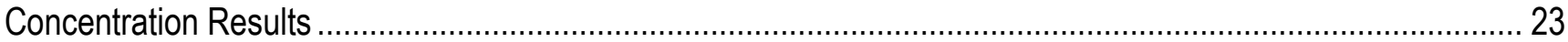

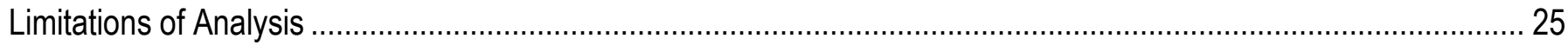

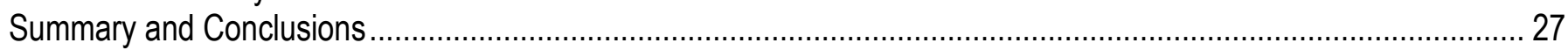

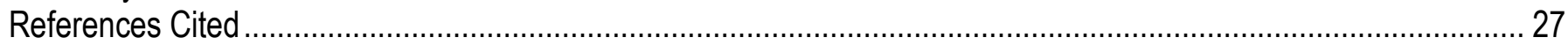

\section{Figures}

Figure 1. Cape Cod, Massachusetts, with coastal embayments, which are underlain by the subterranean estuary. NAD, North American Vertical Datum of 1983; FIPS, Federal information processing standard................. 3

Figure 2. Model grid used in the two-dimensional simulations of flow and solute reactivity in the subterranean estuary in southern coastal Cape Cod, Massachusetts. Model grid exaggerated threefold in the vertical direction. Largest vertical grid spacing is 1 meter $(\mathrm{m})$. Largest horizontal grid spacing is $5 \mathrm{~m}$. Middle panel is an expanded section showing the shore and seabed portion of the grid. The lower panel expands the shore area with head dependent flux boundaries.

Figure 3. Screen captures showing salt concentrations for the two-dimensional SEAWAT hydraulically steadystate model for southern coastal Cape Cod, Massachusetts. $A$, Initial concentration condition without grid; $B$, final result with grid after 2,800 days. Blue indicates freshwater (concentration $=0$ ), and red indicates saltwater (concentration $=1$ ); Yellow area in $B$ is the transition zone with concentrations ranging between 0 and 1 .

Figure 4. Approach to quasi-steady state for the static, mean-tide, two-dimensional SEAWAT simulation for southern coastal Cape Cod, Massachusetts. Total mass of salt in the modeled aquifer is shown for the last 700 days of simulations for each successive simulation. Initial conditions for each simulation were ending conditions of the previous simulation. 
Figure 5. Screen capture showing salt concentration distribution after 6,000 days for the simulation of meantide conditions and the salt level of the initial conditions for southern coastal Cape Cod, Massachusetts......

Figure 6. Screen captures showing two-dimensional SEAWAT development of quasi-steady-state conditions with alternate initial condition 2-freshwater throughout-in an investigation of the subterranean estuary of southern coastal Cape Cod, Massachusetts. Freshwater (blue) is gradually replaced with saltwater (red) from the inflow specified along the seabed boundary. The numbers of days shown in each panel represent the simulation time.

Figure 7. Results of the SEAWAT simulations including fluctuating tide for southern coastal Cape Cod, Massachusetts. Simulations were continued until quasi-steady-state salt conditions were reached.

Figure 8. Detail of water table in the region of groundwater discharge at the coast from a SEAWAT simulation of fluctuating tide at quasi-steady state: $A$, low-tide conditions, $B$, high-tide conditions, $C$, near-surface high- and low-tide salt distribution along cross section a-a', and $D$, high-tide salt distribution to 20 meters depth along cross section a-a'. Extent of the model grid displayed is shown in figure 2. Tidal elevation change is visible as a high elevation of water only at the top of the shore in $A$ and $B$ where drains allow dry cells to form at low tide that fill during high tide. The color wash extends from 0 to 0.1 salinity to emphasize the slight persistence of salt at low tide just below the sediment/water interface. >, greater than.

Figure 9. Solute concentrations in the aquifer at a peninsular coastal site Eel River, in Falmouth, Massachusetts (U.S. Geological Survey, unpub. data, 2014). DO, dissolved oxygen; DOC, dissolved organic carbon; $\mathrm{NO}_{3}+\mathrm{NO}_{2}$, nitrate plus nitrite; $\mathrm{NH}_{4}$, ammonium; NGVD 29, National Geodetic Vertical Datum of 1929; $\mathrm{SpC}$, specific conductance...

Figure 10. Solutes approach quasi-steady state of the aquifer for the PHT3D simulation in an investigation of the subterranean estuary of the southern coast of Cape Cod, Massachusetts. Numbers along the right side of the graphs refer to the sequence of model simulations. $\mathrm{DOM}$, dissolved organic matter; $\mathrm{NH}_{3}$, ammonia; $\mathrm{NO}_{3}$, nitrate; $\mathrm{O}_{2}$, oxygen.

Figure 11. Distribution of solutes in the mean tide PHT3D simulation for the subterranean estuary in southern coastal Cape Cod, Massachusetts, after aquifer mass approaches quasi-steady-state conditions at 6,300 days. Cross section $b-b^{\prime}$ refers to the concentration profiles in figure 12. Color bar concentrations are in molar units. .... 21 Figure 12. Results from the mean-tide PHT3D simulation showing constituent concentration profiles after 6,300 days of simulation across the freshwater/saltwater interface in an investigation of the subterranean estuary of the southern coast of Cape Cod, Massachusetts. Location is section b-b' of figure 11. DOM, dissolved organic matter; $\mathrm{NH}_{3}$, ammonia; $\mathrm{NO}_{3}$, nitrate; $\mathrm{O}_{2}$, oxygen.

Figure 13. Results from the uncalibrated fluctuating-tide PHT3D model in an investigation of the subterranean estuary of the southern coast of Cape Cod, Massachusetts, showing the approach of solutes to equilibrium mass content of the aquifer. Each simulation is 730 days. Numbers in the legends refer to sequence of model simulations. $\mathrm{DOM}$, dissolved organic matter; $\mathrm{NH}_{3}$, ammonia; $\mathrm{NO}_{3}$, nitrate; $\mathrm{O}_{2}$, oxygen.

Figure 14. Distribution of oxygen in the uncalibrated fluctuating-tide PHT3D simulation in an investigation of the subterranean estuary of the southern coast of Cape Cod, Massachusetts, after quasi-steady state in solutes had been reached, with detail shown for the shore area.

\section{Tables}

1. Reactions and kinetic formulae included in the reactive transport model .................................................... 18

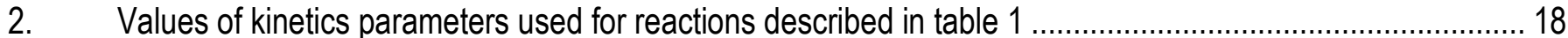

3. Initial concentrations used in the aquifer and concentrations at model boundaries ...................................... 19 


\section{Conversion Factors}

International System of Units to Inch/Pound

\begin{tabular}{|c|c|c|}
\hline Multiply & By & To obtain \\
\hline \multicolumn{3}{|c|}{ Length } \\
\hline meter $(\mathrm{m})$ & 3.281 & foot $(\mathrm{ft})$ \\
\hline kilometer $(\mathrm{km})$ & 0.6214 & mile (mi) \\
\hline \multicolumn{3}{|c|}{ Area } \\
\hline hectare (ha) & 2.471 & acre \\
\hline \multicolumn{3}{|c|}{ Volume } \\
\hline cubic meter $\left(\mathrm{m}^{3}\right)$ & 6.290 & barrel (petroleum, 1 barrel $=42$ gal) \\
\hline liter $(\mathrm{L})$ & 0.2642 & gallon (gal) \\
\hline \multicolumn{3}{|c|}{ Flow rate } \\
\hline cubic meter per second $\left(\mathrm{m}^{3} / \mathrm{s}\right)$ & 70.07 & acre-foot per day (acre-ft/d) \\
\hline cubic meter per year $\left(\mathrm{m}^{3} / \mathrm{yr}\right)$ & 0.000811 & acre-foot per year (acre-ft/yr) \\
\hline cubic hectometer per year $\left(\mathrm{hm}^{3} / \mathrm{yr}\right)$ & 811.03 & acre-foot per year (acre-ft/yr) \\
\hline meter per second $(\mathrm{m} / \mathrm{s})$ & 3.281 & foot per second ( $\mathrm{ft} / \mathrm{s})$ \\
\hline meter per minute $(\mathrm{m} / \mathrm{min})$ & 3.281 & foot per minute (ft/min) \\
\hline meter per hour $(\mathrm{m} / \mathrm{hr})$ & 3.281 & foot per hour (ft/hr) \\
\hline meter per day $(\mathrm{m} / \mathrm{d})$ & 3.281 & foot per day $(\mathrm{ft} / \mathrm{d})$ \\
\hline meter per year $(\mathrm{m} / \mathrm{yr})$ & 3.281 & foot per year ft/yr) \\
\hline cubic meter per second $\left(\mathrm{m}^{3} / \mathrm{s}\right)$ & 35.31 & cubic foot per second $\left(\mathrm{ft}^{3} / \mathrm{s}\right)$ \\
\hline kilometer per hour $(\mathrm{km} / \mathrm{h})$ & 0.6214 & mile per hour $(\mathrm{mi} / \mathrm{h})$ \\
\hline \multicolumn{3}{|c|}{ Mass } \\
\hline kilogram (kg) & 2.205 & pound avoirdupois (lb) \\
\hline \multicolumn{3}{|c|}{ Hydraulic conductivity } \\
\hline meter per day $(\mathrm{m} / \mathrm{d})$ & 3.281 & foot per day $(\mathrm{ft} / \mathrm{d})$ \\
\hline
\end{tabular}

Temperature in degrees Celsius $\left({ }^{\circ} \mathrm{C}\right)$ may be converted to degrees Fahrenheit $\left({ }^{\circ} \mathrm{F}\right)$ as ${ }^{\circ} \mathrm{F}=\left(1.8 \times{ }^{\circ} \mathrm{C}\right)+32$.

Temperature in degrees Fahrenheit $\left({ }^{\circ} \mathrm{F}\right)$ may be converted to degrees Celsius $\left({ }^{\circ} \mathrm{C}\right)$ as ${ }^{\circ} \mathrm{C}=\left({ }^{\circ} \mathrm{F}-32\right) / 1.8$.

\section{Datum}

Vertical coordinate information is referenced to the National Geodetic Vertical Datum of 1929 (NGVD 29).

Horizontal coordinate information is referenced to the North American Datum of 1983 (NAD 83).

Elevation, as used in this report, refers to distance above the vertical datum. 


\section{Abbreviations}

DOM dissolved organic matter

GHB general head boundary

MEP Massachusetts Estuaries Project

$\mathrm{NH}_{3} \quad$ ammonia

$\mathrm{NO}_{3} \quad$ nitrate

$\mathrm{O}_{2} \quad$ oxygen

ppm parts per million

TMDL total maximum daily load

USGS U.S. Geological Survey 


\title{
Simulation of Nitrogen Attenuation in a Subterranean Estuary, Representative of the Southern Coast of Cape Cod, Massachusetts
}

\author{
By John A. Colman, ${ }^{1}$ Carl S. Carlson, ${ }^{1}$ and Clare Robinson ${ }^{2}$
}

\begin{abstract}
A two-dimensional model was developed by the U.S. Geological Survey, in cooperation with the U.S. Environmental Protection Agency, to assess flow and chemical reaction associated with groundwater discharge through the subterranean estuary representative of coastal salt ponds of southern Cape Cod. The model simulated both the freshwater and saltwater flow systems and accounted for density-dependent flow, tidal fluctuation, and chemical reactivity among oxygen, dissolved organic carbon, nitrate, and ammonia. Not previously incorporated into one model, the interaction of these effects can now be simulated in the subterranean estuary context.

An analysis of the flow system under mean-tide conditions was conducted first to provide the initial conditions for a subsequent analysis that included the effects of tidal fluctuations. Tidal fluctuations were simulated with a repeated couplet that represented a high tide-low tide sequence and alternating locations of head-dependent flux boundaries placed along the simulated seabed, above and below the levels of the respective high and low tides.

Boundary conditions for chemical species included nitrate in recharge, and oxygen and organic matter (including organic nitrogen) in infiltrating solutions of head-dependent boundaries. Reaction chemistry was limited to oxidative degradation of organic matter (including remineralization of ammonia) with oxygen or nitrate as electron acceptors and nitrification of ammonia in the presence of oxygen.
\end{abstract}

Simulations using the SEAWAT-2000 computer program resulted in two mixing zonesbetween freshwater and saltwater in a deep saltwater wedge and in an intertidal salt zone, which results from tidal fluctuation. The mixing zones are the principal locations where nitrogen attenuation reactions occurred-between organic matter in the saltwater zones of the aquifer and nitrate in the freshwater zone.

In mean-tide PHT3D model simulations, 15 percent of nitrogen that is recharged was attenuated because of reaction with dissolved organic matter, a denitrification reaction that reduces nitrate to nitrogen gas. When a fluctuating tide was simulated, the amount of recharged nitrogen that was denitrified increased to 20 percent.

Chemical reaction was controlled by the rate of mixing of freshwater and saltwater, which contained the reactants nitrate and dissolved organic matter, respectively, necessary for nitrogen attenuation reactions to take place. Reaction occurred in both the deep saltwater wedge and in an

\footnotetext{
${ }^{1}$ U.S. Geological Survey.

${ }^{2}$ Western University in London, Ontario, Canada.
} 
increased denitrification. However, mixing may also have been enhanced partly by numerical dispersion.

\section{Introduction}

Nutrient pollution is one of coastal New England's most widespread, costly, and challenging environmental problems. On Cape Cod, Massachusetts (fig. 1), nitrogen loading to embayments and the resulting eutrophication of these coastal waters are among the most pressing environmental challenges faced by communities today. Degradation of aquatic ecosystems by nitrogen loading threatens fundamental parts of the Cape Cod economy, such as the tourism and fishing industries.

Recognizing the importance of nitrogen in Cape Cod eutrophication, the Massachusetts Department of Environmental Protection in 2000 established the Massachusetts Estuaries Project (MEP) to evaluate nitrogen loading and capacity in 89 Cape Cod embayments (Massachusetts Department of Environmental Protection, 2003). This effort is ongoing, but in approximately one-half of the target embayments, evaluations have resulted in total maximum daily loads (TMDLs) that establish regulatory numeric nitrogen loading limits (Massachusetts Estuaries Project, 2011). Currently [2014], Massachusetts towns included in the MEP are weighing alternative nitrogen remediation actions to meet the TMDL requirements.

In much of the Cape Cod aquifer, where subsurface conditions are aerobic and the nitrogen form is nitrate, transport is likely to be conservative so that attenuation reactions do not need to be considered. Where subsurface conditions are anaerobic, however, large amounts of nitrogen can be attenuated - converted to nitrogen gas, which is unavailable to algae, or to ammonium ion, which is slowed greatly in subsurface transport rate. Such conditions occur in landfill plumes, large plumes of municipal or military-base sewage disposal, and the subterranean estuary (area at the coastline below the sediment layer where freshwater and saltwater mix). Of these potential nitrogen attenuation zones, the subterranean estuary is least investigated, although much of the nitrogen entering environmentally sensitive coastal embayments passes through the subterranean estuary during discharge to marine water.

\section{Synopsis of Previous Modeling Efforts}

Past investigations of the subterranean estuary on Cape Cod (fig. 1) have focused on the upper end of Waquoit Bay, Falmouth, Mass. (Belaval and others, 2003; Michael and others, 2003, 2005; Kroeger and Charette, 2008; Spiteri and others, 2008; Abarca and others, 2013), Red Brook Harbor, Falmouth (McCobb and LeBlanc, 2002), and Salt Pond on outer Cape Cod (Crusius and others, 2005; Cross and others, 2008). Only the work at Waquoit Bay included calculation of nitrogen loss in the subterranean estuary. The Waquoit Bay subterranean estuary has some atypical features, such as low tidal amplitude, generally low concentrations of nitrogen in the discharging freshwater, and an ammonia plume over a nitrate plume, as well as more typical features, principally a deep saltwater wedge underlying the freshwater discharge. These atypical features and contradictory conclusions in the scientific literature leave uncertain the transferability of the Waquoit Bay results to other Cape Cod subterranean estuary locations. 


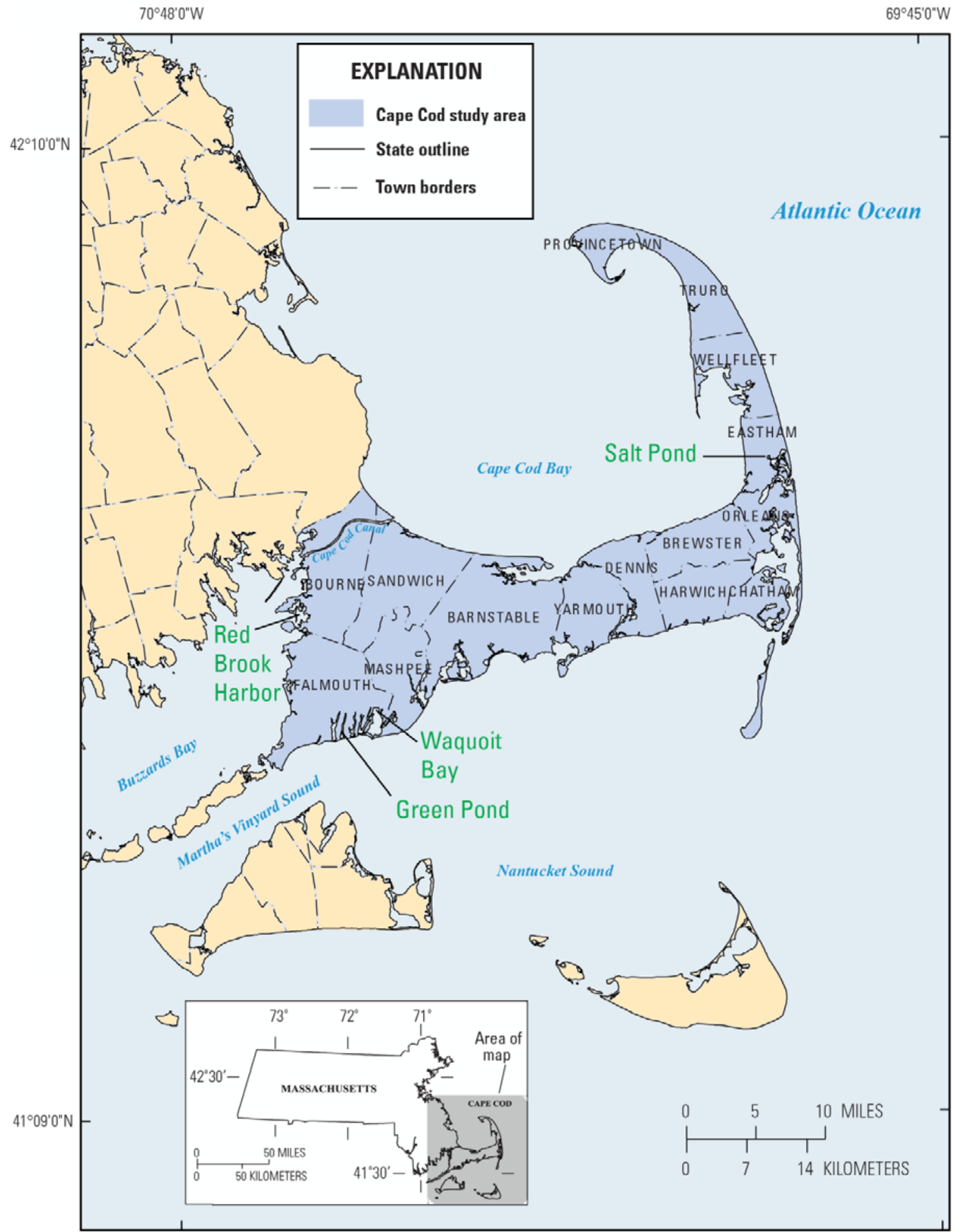

Basefrom USGS digital line graphs, scale 1:25,000 NAD 1983, Massachusetts state plane FIPS 2001

Lambert Conformal Conic Projection

Figure 1. Cape Cod, Massachusetts, with coastal embayments, which are underlain by the subterranean estuary. NAD, North American Vertical Datum of 1983; FIPS, Federal information processing standard. 
One difficulty with assessing nitrogen loss in the subterranean estuary is in relating subsurface concentration measurements to flux, which requires knowledge of both the concentration of nitrogen and groundwater flow. Flow is difficult to measure directly in the subsurface, particularly with fluctuating heads associated with tidal conditions. A well-posed flow and reactive-solute transport model could potentially overcome these difficulties by simulating flow and concentration and yielding flux. A sensitivity analysis conducted with such a model could be used to determine the factors most affecting nitrogen loss in the subterranean estuary.

To date, two-dimensional (2D) models of solute transport, including density effects and tidal fluctuation, but without chemical reactivity (Abarca and others, 2013), and including density and chemical reactivity, but without tidal fluctuation (Spiteri and others, 2008), have been developed for the Waquoit Bay subterranean estuary. All of these forcing functions were included in a recent 2D model by Anwar and others (2014), which used a high-hydraulic-conductivity ocean (Mulligan and others, 2011). A generic 2D model that includes density, reactivity, and tidal fluctuation for the subterranean estuary and the general head boundary approach, rather than a high-hydraulic-conductivity ocean (Mulligan and others, 2011), was developed as part of the project conducted by the U.S. Geological Survey in cooperation with the U.S. Environmental Protection Agency to simulate ranges of nitrogen attenuation that are possible given literature values of nitrogen reactivity and representative rates of groundwater flow and tidal fluctuation.

\section{Purpose and Scope}

This report describes the development of a 2D reactive-solute-transport groundwater model that was used to simulate nitrogen transport, including the density effects of mixing saltwater and freshwater, tidal forcing, and nitrogen attenuation chemistry. Although the model is generic and is not calibrated in either flow or chemistry, parameters used were characteristic of southern coastal Cape Cod conditions so that results would apply depending on the extent to which assumed parameter values are correct for a given site. Assumed values for many of the parameters were based on field assessments from a concurrent investigation at a coastal pond in Falmouth (fig. 1). However, key parameters such as hydrologic conductivity and rate of reaction for ocean-derived organic matter, were from literature rather than measured values. As such, the model can be used to assess the possibility of whether nitrogen can decrease because of attenuation reactions during transport through the subterranean estuary. Determination of the actual amount of attenuation for a given site would require model calibration.

\section{Sources and Quality of Model Data}

Excellent sources of hydrogeologic and geochemical data were available from investigations of groundwater flow and transport in the Cape Cod aquifer system conducted by the U.S. Geological Survey (USGS) over the past 30 years (1985-2014). Much of these data have been described in past reports (Savoie and LeBlanc, 1998; Repert and others, 2006; Barbaro and others, 2013). The data were quality checked and stored in USGS electronic databases.

Hydraulic properties and the physical extent of the aquifer needed for the simulation of groundwater flow were based on existing, documented groundwater models of the Cape Cod aquifer system (Walter and Whealan, 2005; Walter, 2008) at the location of the peninsula west of Green Pond (fig. 1). The model extent is based roughly from the groundwater divide of the peninsula east to the center of Green Pond. The relevant chemical processes that affect reactive nitrogen transport and attenuation were reproduced by model algorithms built into the PHREEQC modeling software 
(Parkhurst and Appelo, 1999), which controls the kinetic reactions implemented through the PHT3D modeling software (Prommer and Post, 2010). Recent literature formulations of biologically mediated reactions and reaction rates were used to establish nitrogen attenuation by denitrification in the subterranean estuary (Colman and others, 2004; Smith and others, 2004; Spiteri and others, 2008; Robertson and others, 2011).

\section{Model Development and Approach}

The USGS SEAWAT-2000 (SEAWAT) finite difference simulation code (Langevin and others, 2003) was used to simulate variable-density groundwater flow and transport in the analysis in this report. The flow field from the SEAWAT simulations then was used to provide the framework for simulation of chemistry by use of the reactive-solute-transport code PHT3D (Prommer and Post, 2010). The model development described in this report includes the following steps:

1. Step 1, a 2D quasi-steady-state, or dynamic equilibrium, variable-density model was used to establish the freshwater and saltwater flow field for mean-tide conditions;

2. Step 2, the ending heads and salinity distribution established in step 1 were used as the initial conditions in a dynamic equilibrium model of tidal fluctuation to establish the flow field and salinity distribution for fluctuating tide;

3. Step 3, the flow field of step 1 was used in a quasi-steady-state reactive-solute-transport model to assess nitrogen attenuation for mean-tide conditions; and

4. Step 4 , the flow field of step 2 was used with the quasi-steady-state solute content of step 3 as initial conditions in a reactive-solute-transport model to assess nitrogen attenuation under changing tidal position.

\section{Model Grid}

The model was designed to extend horizontally 425 meters $(\mathrm{m})$ - the distance from a theoretical onshore groundwater divide to the shoreline - and then an additional $99.8 \mathrm{~m}$ offshore. The vertical extent of $87.6 \mathrm{~m}$ stretches from the land surface to bedrock (fig. 2). 


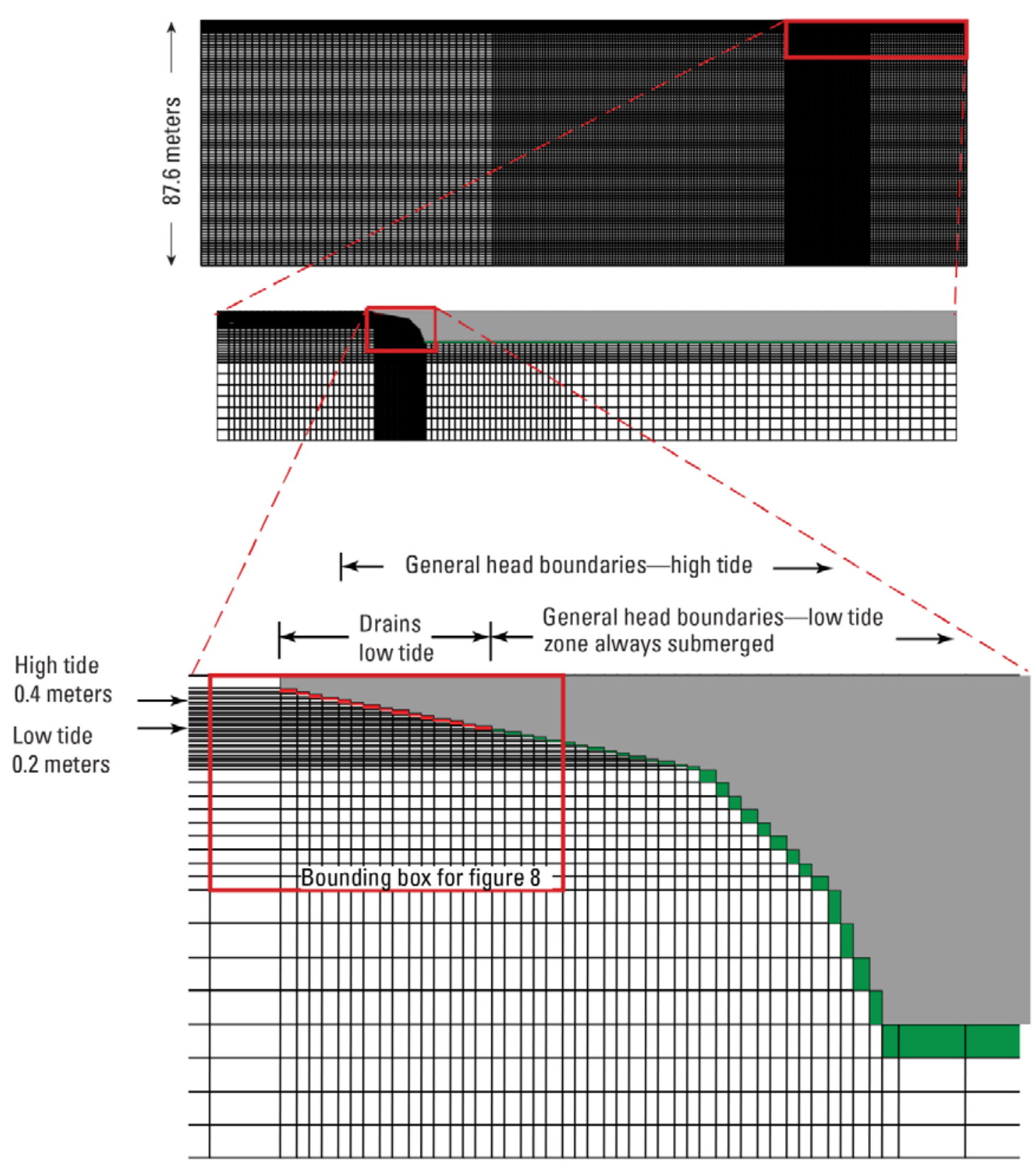

\section{EXPLANATION}

No flow boundary cells

General head boundary cells, for low tide case

Drain boundary cells, for low tide case

Figure 2. Model grid used in the two-dimensional simulations of flow and solute reactivity in the subterranean estuary in southern coastal Cape Cod, Massachusetts. Model grid exaggerated threefold in the vertical direction. Largest vertical grid spacing is $1 \mathrm{~meter}(\mathrm{~m})$. Largest horizontal grid spacing is $5 \mathrm{~m}$. Middle panel is an expanded section showing the shore and seabed portion of the grid. The lower panel expands the shore area with head dependent flux boundaries. 
The model grid had a variable cell size where cells in the vicinity of the shoreline are smaller in area than cells at the model boundaries. The 2D model included 1 row of 267 columns. The aquifer was divided into 135 layers - from an elevation of $0.6 \mathrm{~m}$ (above the National Geodetic Vertical Datum of 1929 [NGVD 29]) at land surface to a depth of $87 \mathrm{~m}$ (below NGVD 29) - the top of the bedrock surface in the vicinity of the salt ponds in southwestern Cape Cod (Fairchild and others, 2013). The layers were horizontal and varied in thickness $-0.1 \mathrm{~m}$ for layer $1,0.02 \mathrm{~m}$ for layers 2 through $31,0.1 \mathrm{~m}$ for layers 32 through $40 ; 0.25 \mathrm{~m}$ for layers 41 through 52, and $1.0 \mathrm{~m}$ for layers 53 through 135 . The width of the single row was specified to be $5 \mathrm{~m}$. The overall cumulative width of the model columns was $524.8 \mathrm{~m}$, and individual column widths varied from west (column 1) to east (column 267) $-5 \mathrm{~m}$ for columns 1 through 40, $2 \mathrm{~m}$ for columns 41 through 140, $1 \mathrm{~m}$ for columns 141 through 165, $0.2 \mathrm{~m}$ for columns 166 through 209 (those cells corresponding to the shoreline), $1 \mathrm{~m}$ for columns 210 through 234 (cells that represent the proximal seabed), and $2 \mathrm{~m}$ for columns 235 through 267 (cells that represent the distal seabed).

A very fine discretization of the model grid was required in the vicinity of the shoreline because of the dynamic and highly spatially varying flows induced in this vicinity for the simulations with tidal fluctuations. The grid size affects the mixing rates simulated through numerical dispersion. Many chemical reactions are determined by rates of mixing fresh groundwater and recirculating seawater and so can be affected by grid size.

\section{Boundary Conditions}

All cells corresponding to the onshore model area were active, whereas cells corresponding to the saline surface-water column were made inactive. No-flow boundaries were specified along the left and right vertical boundaries and the horizontal bottom boundary. A recharge rate of 0.00167 meter per day $(\mathrm{m} / \mathrm{d} ; 24$ inches per year $[\mathrm{in} / \mathrm{yr}])$ was specified in the uppermost active cells. This rate is consistent with previous analyses of the coastal aquifers in southwestern Cape Cod (Walter and Whealan, 2005).

The interface between the nearshore area of groundwater discharge from the aquifer during low tide and inflow of saline surface water during high tide was simulated with a combination of headdependent flux boundaries - the General-Head Boundary (GHB) and Drain (DRN) packages of MODFLOW-2000 (Harbaugh and McDonald, 1996; Harbaugh and others, 2000) - according to the methods described in Mulligan and others (2011). Assignment of these boundary conditions depended on sea-level position associated with changing tides (fig. 2). For the mean-tide simulation, the tide level was set to be $0.3 \mathrm{~m}$, a value consistent with those of the coastal embayments in southwestern Cape Cod. GHB cells were specified at and below the mean-tide elevation in each uppermost active cell in each column that represented the seabed. Model cells located above the seabed were not active. The specified head and salt concentration of seawater in each GHB cell were set to values of $0.3 \mathrm{~m}$ and 1 , respectively. The salt concentration of seawater can be represented by a value of 1 because only the density effects (not the effects of chemical reaction) were being simulated with SEAWAT. DRN cells were specified in the uppermost active cells above the mean tide level, up to but not including layer 1.

\section{Hydraulic Properties}

Hydraulic properties of the sediments represented in the groundwater model were similar to those of a calibrated model of central and western Cape Cod (Walter, 2008). Horizontal hydraulic conductivity was $50.9 \mathrm{~m} / \mathrm{d}$ (167 feet per day [ft/d]) with a vertical hydraulic conductivity of $10.18 \mathrm{~m} / \mathrm{d}$ $(33.4 \mathrm{ft} / \mathrm{d})$. The hydraulic conductivity values were constant throughout the entire model area. Porosity and specific yield were set equal to 0.3 . The seabed leakance was set to a uniform value of $0.152 \mathrm{~m} / \mathrm{d}$ 
$(0.5 \mathrm{ft} / \mathrm{d})$. The conductance value assigned to the GHB and DRN cells varied according to cell size (Harbaugh and McDonald, 1996; Harbaugh and others, 2000).

\section{Initial Salt Concentrations}

The SEAWAT model code requires an initial salt concentration to differentiate between the freshwater and saltwater flow systems. Two zones of initial salt concentration for freshwater and saltwater (concentration values of 0 and 1, respectively) were specified in the model (fig. 3), based on the approximate depth of the interface between the freshwater and saltwater flow systems as indicated by the Gyben-Herzberg relation (Fetter, 1994; Barlow, 2003).

$\boldsymbol{A}$

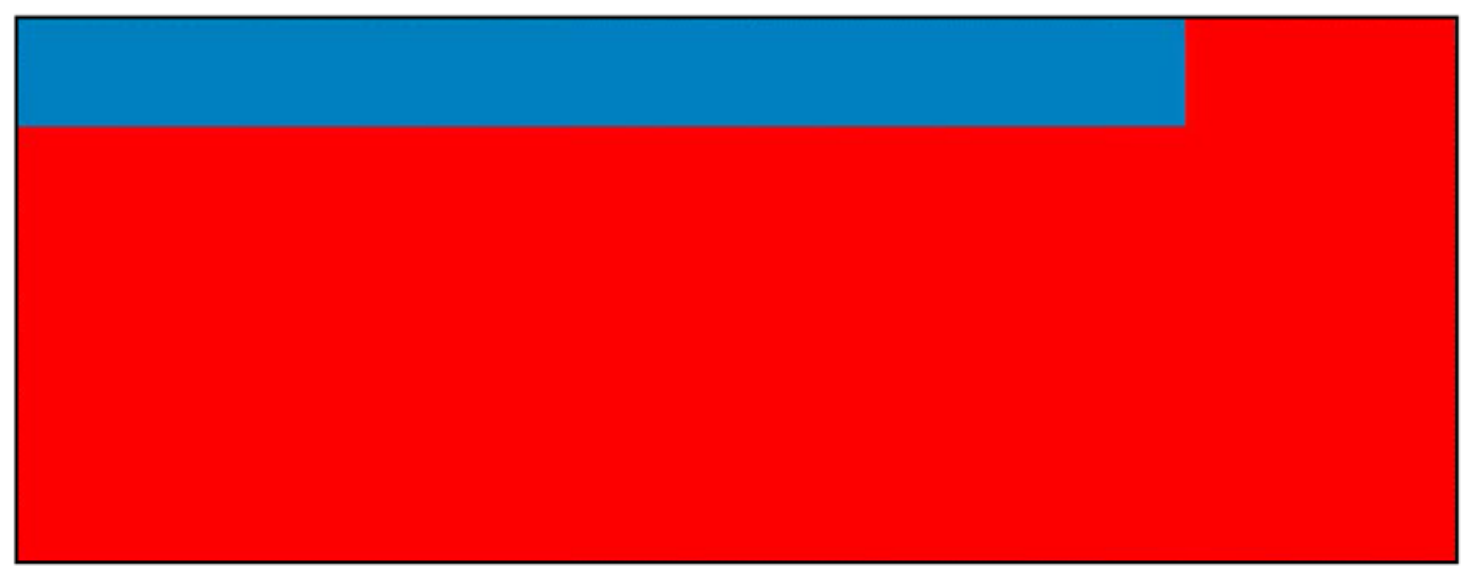

B

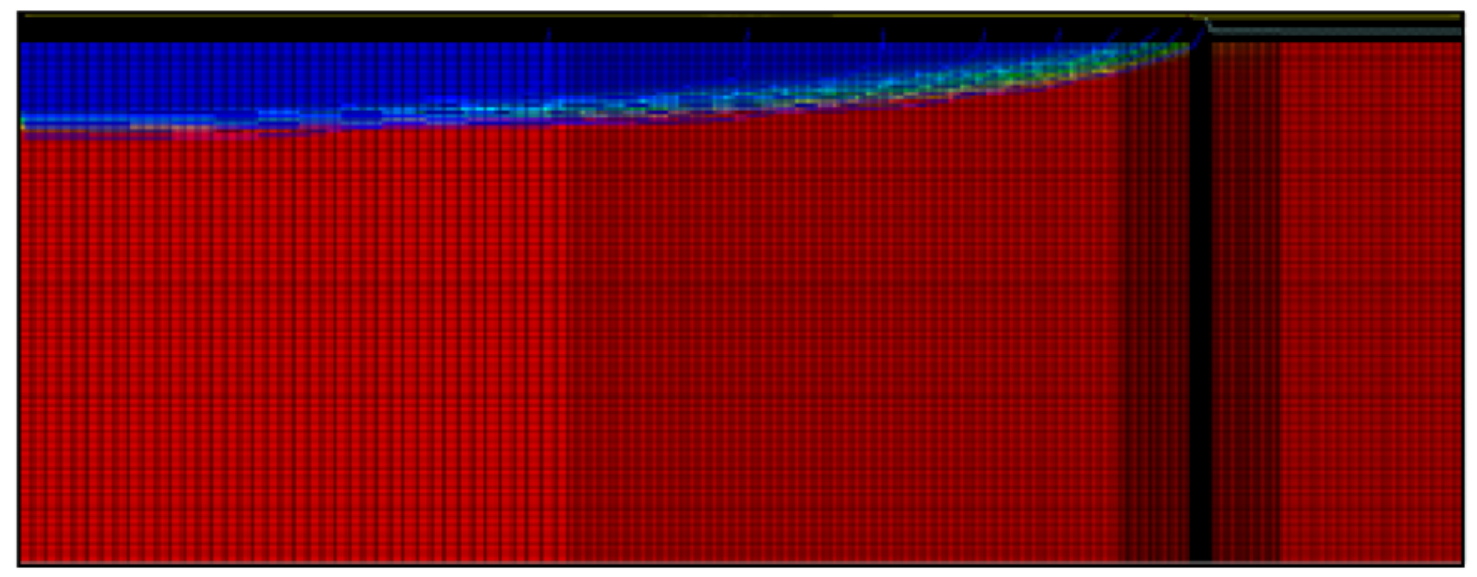

Figure 3. Screen captures showing salt concentrations for the two-dimensional SEAWAT hydraulically steady-state model for southern coastal Cape Cod, Massachusetts. $A$, Initial concentration condition without grid; $B$, final result with grid after 2,800 days. Blue indicates freshwater (concentration $=0$ ), and red indicates saltwater (concentration =1); Yellow area in $B$ is the transition zone with concentrations ranging between 0 and 1 . 


\section{Simulation of Long-Term Mean-Tide Conditions}

Simulations included constant tidal forcing at mean sea level (step 1, "Model Development and Approach" section) and changing sea-level forcing (step 2) so that flow and chemistry could be compared to determine the effect of tidal exchange. The SEAWAT step 1 simulation achieved a quasisteady-state condition by 2,800 simulated days, that is, the total solute mass in the model did not change appreciably over time (fig. 4; Guo and Langevin, 2002). The resulting head and salt concentration values were used as starting conditions for subsequent simulations of the tidal-fluctuation effects (step 2).

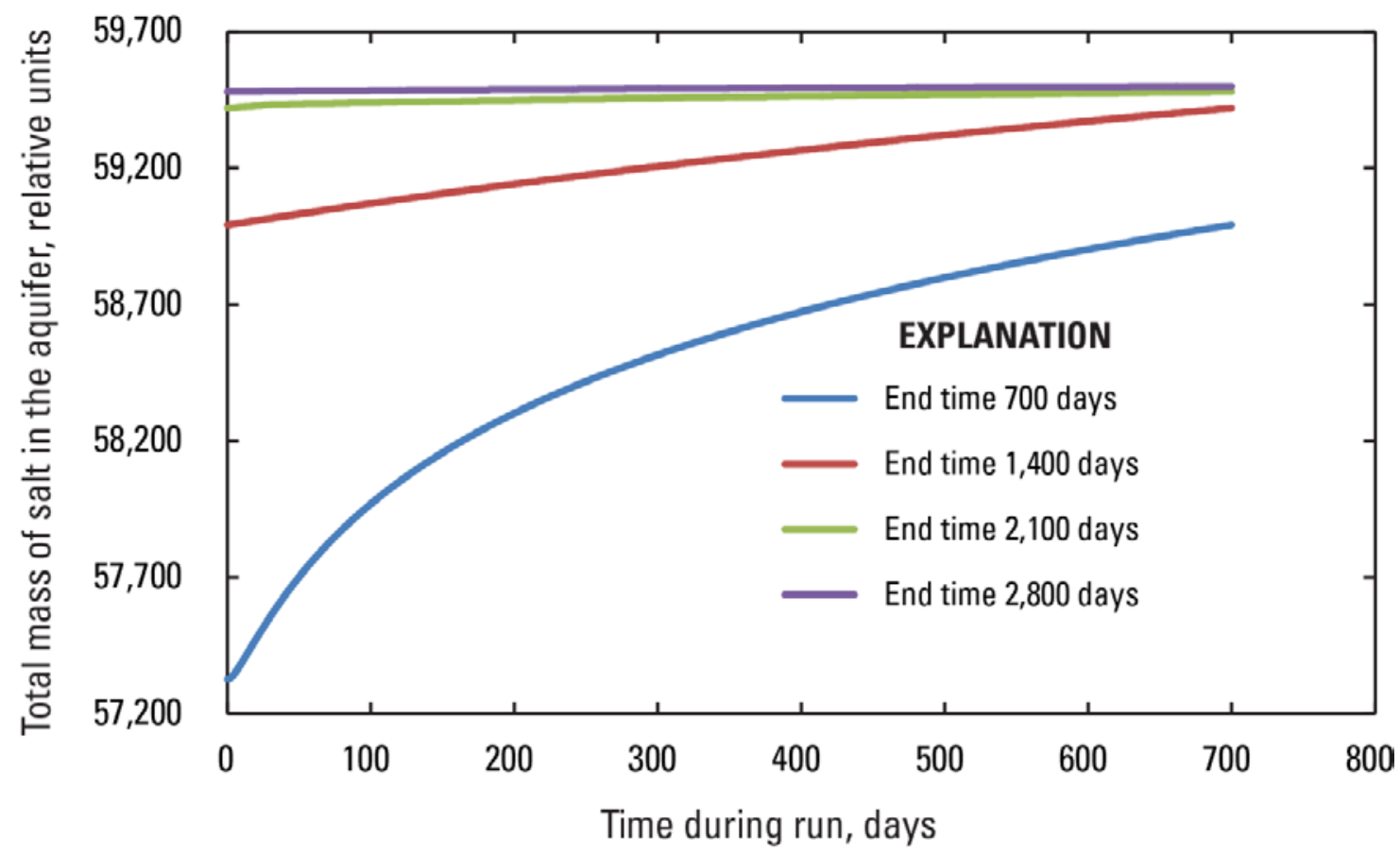

Figure 4. Approach to quasi-steady state for the static, mean-tide, two-dimensional SEAWAT simulation for southern coastal Cape Cod, Massachusetts. Total mass of salt in the modeled aquifer is shown for the last 700 days of simulations for each successive simulation. Initial conditions for each simulation were ending conditions of the previous simulation.

\section{Sensitivity Analysis of the Effect of Initial Salt Concentration Distributions on the Final Distribution}

After the model achieved a quasi-steady-state solution with respect to salinity distribution, the simulated freshwater/saltwater interface position (at $-14 \mathrm{~m}$ elevation) was similar to the initial interface position specified in the initial concentration condition $(-17 \mathrm{~m})$, except near the shoreline transition zone (fig. 3B). Therefore, in order to verify that the final freshwater/saltwater interface position represented a unique numerical solution for the model setup, alternative initial salt concentration conditions were simulated, as follows: 
1. Condition 1, the elevation of the interface between the initial freshwater and saltwater concentrations was lowered by $24 \mathrm{~m}$, and

2. Condition 2, the initial salt concentration was set to 0 everywhere (in other words, freshwater was present throughout the entire subsurface), so the only source of saltwater into the system was from inflow from the GHB cells at the seabed.

Because a quasi-steady-state solution was achieved by about 2,800 days in the initial simulation, simulation periods longer than 2,800 days were used for each alternative initial salt concentration distribution simulation. For alternate condition 1 , quasi-steady state was achieved by about 6,000 days (fig. 5). The freshwater/saltwater interface position from this simulation was nearly identical to that of the base case (initial simulation; fig. $3 B$ ).

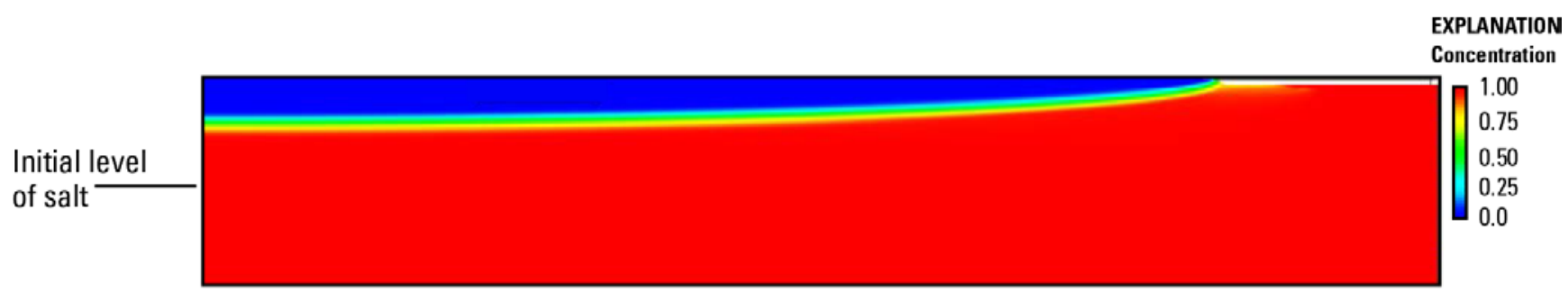

Figure 5. Screen capture showing salt concentration distribution after 6,000 days for the simulation of meantide conditions and the salt level of the initial conditions for southern coastal Cape Cod, Massachusetts.

For alternate salt-concentration condition 2, a quasi-steady-state solution was achieved after about 11,000 days (fig. 6). The initial condition of freshwater everywhere was replaced by a saltwater area that gradually increased in size over simulated time. After a simulation period of 11,000 days, the elevation of the interface between freshwater and saltwater approached that reached in the original and condition 1 simulations. 

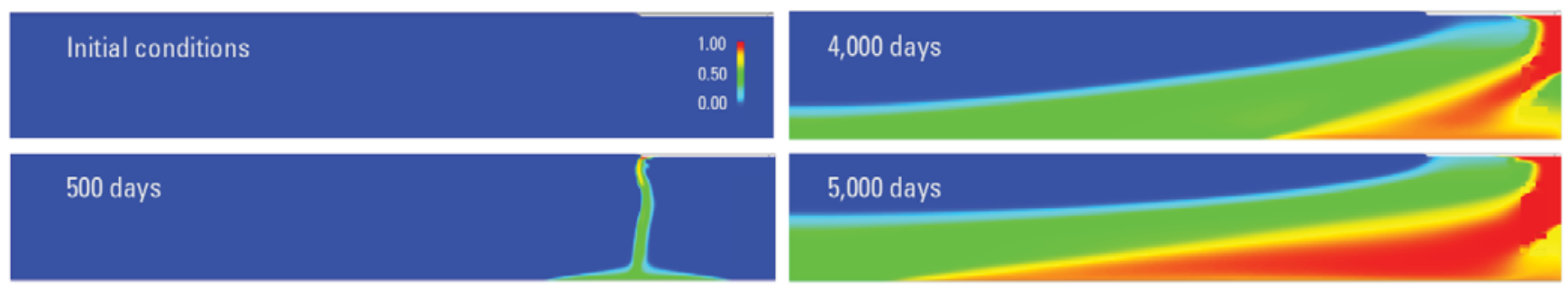

5,000 days

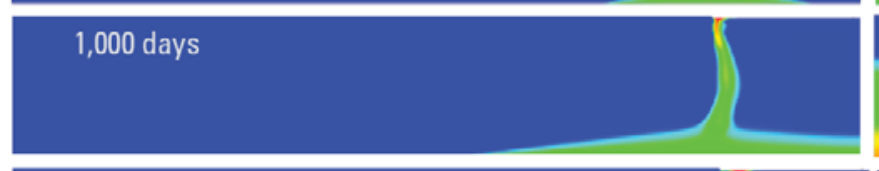

6,000 days
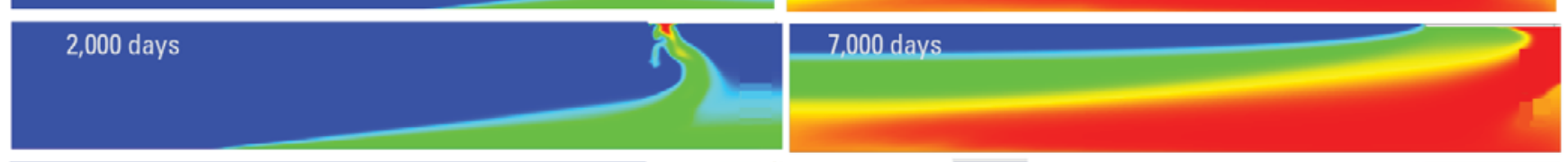

3,000 days

- Base-case intertace

11,000 days

Figure 6. Screen captures showing two-dimensional SEAWAT development of quasi-steady-state conditions with alternate initial condition 2-freshwater throughout-in an investigation of the subterranean estuary of southern coastal Cape Cod, Massachusetts. Freshwater (blue) is gradually replaced with saltwater (red) from the inflow specified along the seabed boundary. The numbers of days shown in each panel represent the simulation time.

The resulting elevation of the freshwater/saltwater interface for these alternative initial salt concentration scenarios for quasi-steady-state conditions was similar to the interface elevation of the base case. One difference to note in the results for alternate condition 2 is that the mixing zone is thicker or more dispersed than those for the base case or alternative condition 1. It is thought that, if the simulation for alternative condition 2 were run for a much longer time, the dispersion of the mixing zone would decrease and approach that of the other simulations. The fact that, regardless of the initial salt concentration distribution, the final solutions appear to be similar indicates that the final results are not affected by the initial concentration distribution.

\section{Simulation With Tidal Fluctuations}

Tidal fluctuations acting on a shoreline result in pulses of saline surface water moving into the sediments at the shoreline during high tide and the subsequent draining of this saline water from the aquifer during low tide. This effect of tidal fluctuations was examined by simulating a small-amplitude tide $(0.2 \mathrm{~m})$, which occurs in some of the embayments on the southern shore of Cape Cod (step 2, "Model Development and Approach" section).

The ocean tides were simulated by a series of alternating tidal positions that represented high tide and low tide over a 12-hour tidal cycle. The GHB and DRN packages of MODFLOW-2000 (Harbaugh and others, 2000) were used as a means of simulating high-tide and low-tide conditions, as described in the "Boundary Conditions" section. Only high- and low-tide levels were simulated in the model. There were no intermediate tide levels, and the high- and low-tide levels used were the same from one tide cycle to the next. As in the mean-tide simulation, the GHB cells represented the head in the ocean, and the GHB was assigned to cells that represented the seabed starting at the shoreline. The 
DRN cells represented shoreline cells above each tidal level. Thus the number of GHB and DRN cells changed for each stress period, depending on the tide elevation. In a stress period representing high tide, GHB cells were specified at and below the high-tide elevation of $0.4 \mathrm{~m}$ in the uppermost active cell in each layer that corresponded to the shoreline and the seabed. In a stress period representing low tide, GHB cells were specified at and below the low-tide elevation of $0.2 \mathrm{~m}$ in the uppermost active cell in each layer that corresponded to the shoreline and the seabed. The salt concentration of infiltrating water of the GHB was set to 1 (seawater).

The tidal-fluctuation simulation began with an initial stress period of 1 day in length that represented the mean-tide position. The subsequent stress periods were then used to represent the changing tide elevation. The head and concentration values resulting from the mean-tide simulation (step 1, "Model Development and Approach" section) were used as the initial conditions for the tidal fluctuation simulation. The tidal fluctuation simulation included 731 days of simulated time. The total number of stress periods was 2,921 with an initial 1-day period followed by 2,920 periods of 0.25 days each. These quarter-day stress periods simulated one 6-hour tide, and each day consisted of an alternating sequence of high and low tides.

Salt in the aquifer increased slightly during the tidal simulation by about 0.02 percent (fig. 7). For each subsequent simulation, the initial head value and salt concentration were the final conditions of the previous simulation. The rate of increased salt concentration diminished during successive simulations, reaching a new quasi-steady-state level in the fourth simulation from 2,192 to 2,923 days (fig. 7).

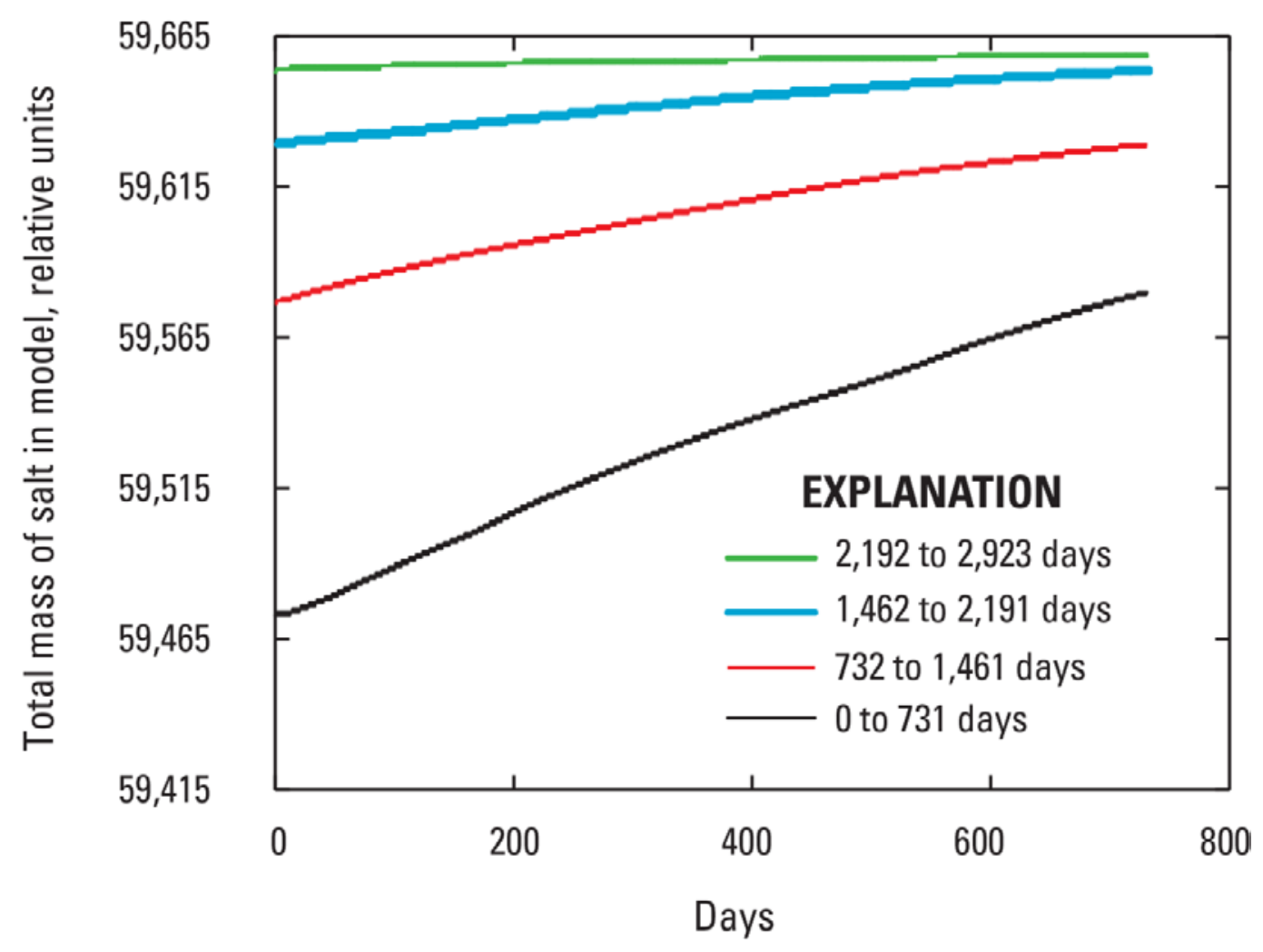

Figure 7. Results of the SEAWAT simulations including fluctuating tide for southern coastal Cape Cod, Massachusetts. Simulations were continued until quasi-steady-state salt conditions were reached. 
The change in hydraulic head resulting from tidal fluctuation may be discerned by the difference in filled models cells in DRN-boundary portions active model (fig. 8). Movement of salt into and out of the aquifer is also apparent along the sloping shore between the high- and low-tide elevations.

\section{$\boldsymbol{A}$}

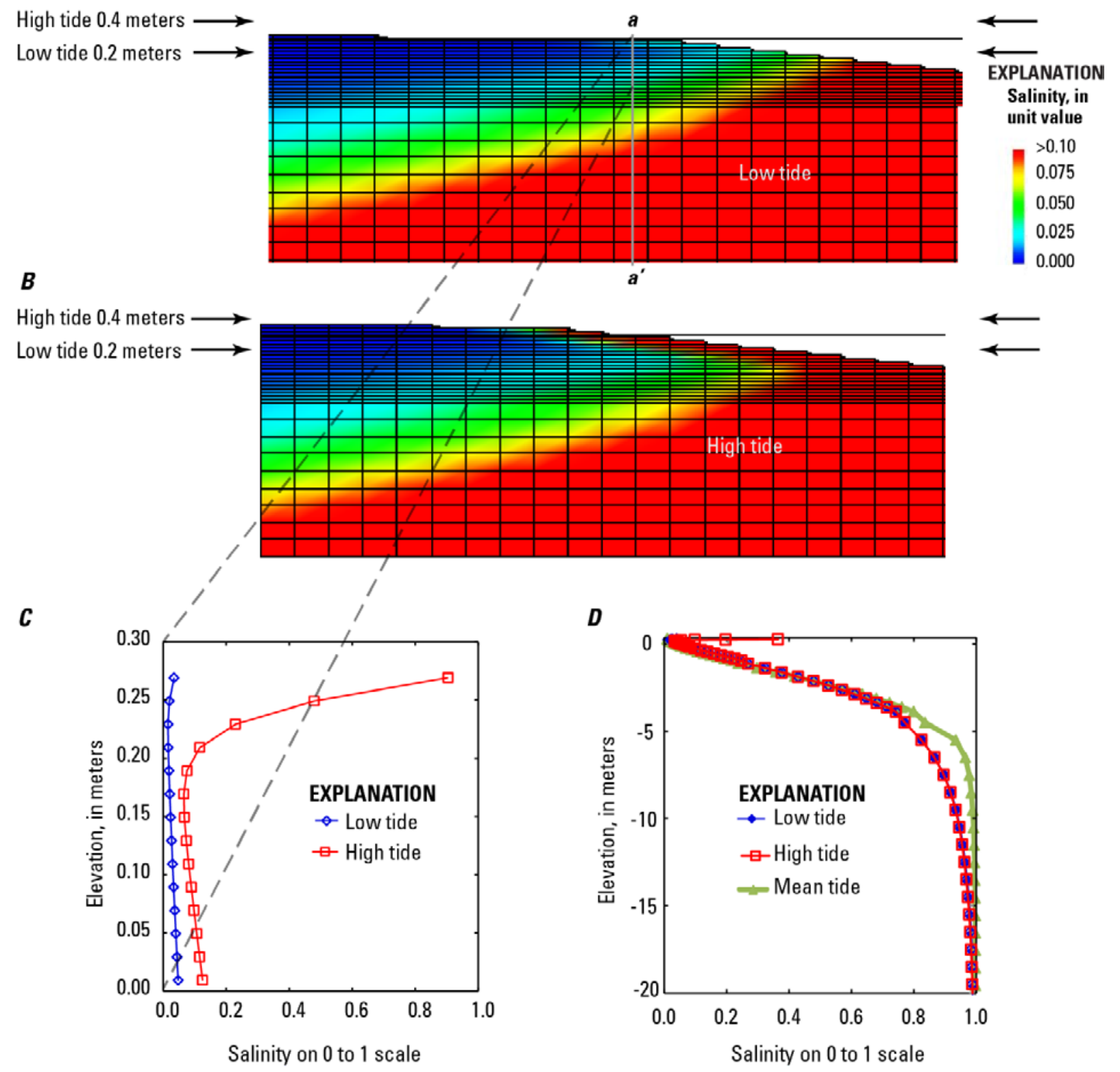

Figure 8. Detail of water table in the region of groundwater discharge at the coast from a SEAWAT simulation of fluctuating tide at quasi-steady state: $A$, low-tide conditions, $B$, high-tide conditions, $C$, near-surface high- and low-tide salt distribution along cross section a-a', and $D$, high-tide salt distribution to 20 meters depth along cross section a-a'. Extent of the model grid displayed is shown in figure 2. Tidal elevation change is visible as a high elevation of water only at the top of the shore in $A$ and $B$ where drains allow dry cells to form at low tide that fill during high tide. The color wash extends from 0 to 0.1 salinity to emphasize the slight persistence of salt at low tide just below the sediment/water interface. >, greater than. 


\section{Comparison of Mean-Tide and Fluctuating-Tide Simulations}

Mean tide was simulated to develop initial conditions for fluctuating tide but also to determine flow differences and their significance between the fluctuating and constant-head treatments. With constant head, there is no mixing at the surface, so reactions that might result from seawater mixing with freshwater cannot happen. The tidal-fluctuation simulation indicates that, at high tide, salt enters the subsurface evenly along the shore slope (fig. $8 B$ ). The degree of mixing is small in the simulation, but salt introduced at high tide persists during low tide (fig. $8 A$ ). With persistently mixed waters, reactions between solutes in saltwater and freshwater are possible, even for those reactions with slow kinetics.

The persistence of some salt at low tide in the intertidal zone compared with the complete removal of salt by groundwater discharging seaward indicates that discharge is more pronounced seaward of the intertidal salt cell than in the intertidal zone. This effect has been found in other investigations of coastal discharge that include density and tidal fluctuation effects (Abarca and others, 2013).

Mixing of freshwater and saltwater at the deep saltwater wedge is also enhanced by tidal fluctuation, as shown by comparison to the constant head ocean. The mixing is reflected in the salt concentration gradients with depth (fig. $8 D$ ). A steep gradient indicates less mixing, and a gradual gradient indicates more mixing. Just as at the surface, the increased mixing of saltwater and freshwater at the deep interface would cause any reactions that result from that mixing to increase.

Most tides are larger than that simulated here and include variable heights, which increase mixing (Abarca and others, 2013). The subtle effects described here would likely be magnified at greater tidal heights. The means to simulate the effects are included in this model and could be applied in simulations with greater or variable tides. An advantage of this SEAWAT modeling platform is that it can support chemistry simulations as well, as described in the "Simulation of Nitrogen Attenuation With a Model of Reactive-Solute Transport" section.

\section{Simulation of Nitrogen Attenuation With a Model of Reactive-Solute Transport}

The previously described simulations developed by using the SEAWAT code, which includes salinity/density effects, provide the flow field needed for simulations of reactive-solute transport of ecologically important substances, such as nitrogen. Reactions involving solutes generally occur with mixing of waters, such as freshwater and saltwater, that contain the solute reactants. Mixing of saltwater and freshwater was simulated in the deep saltwater wedge and in the intertidal region, where saltwater moves over freshwater during high tide and rewets areas that have drained (fig. 8). These are areas that were investigated for chemical reactions by using the reactive-solute transport code of PHT3D. 


\section{Geochemical Environment}

Few investigations of geochemical conditions in the aquifer of southern coastal Cape Cod have been conducted. Several studies focused on the shore zone at Waquoit Bay. There, a low oxygen ammonia plume overlies an oxic nitrate plume, which in turn overlies a saltwater wedge (Spiteri and others, 2008). This may differ from the peninsular southern coast because of the low housing density and freshwater ponds in the small contributing area of the Waquoit Bay northern shore; the peninsulas have dense housing and lack freshwater ponds. A recent investigation in the dense housing area near Eel River, Falmouth, found low oxygen concentrations (less than $[<] 4.0$ micromolar at 9 of 12 depths; $<16.0$ micromolar at the other 3 depths) throughout the aquifer above the freshwater/saltwater interface at -13 m elevation (fig. 9; U.S. Geological Survey unpub. data, 2014). The Eel River site shows conditions that might result in denitrification because oxygen is largely gone and high concentrations of nitrate are present. Concentrations of organic matter, necessary for denitrification, are generally low but increase deep in the aquifer where concentrations of salt also increase. With mixing, organic carbon in the saltwater could react with nitrate in the freshwater, resulting in denitrification. 


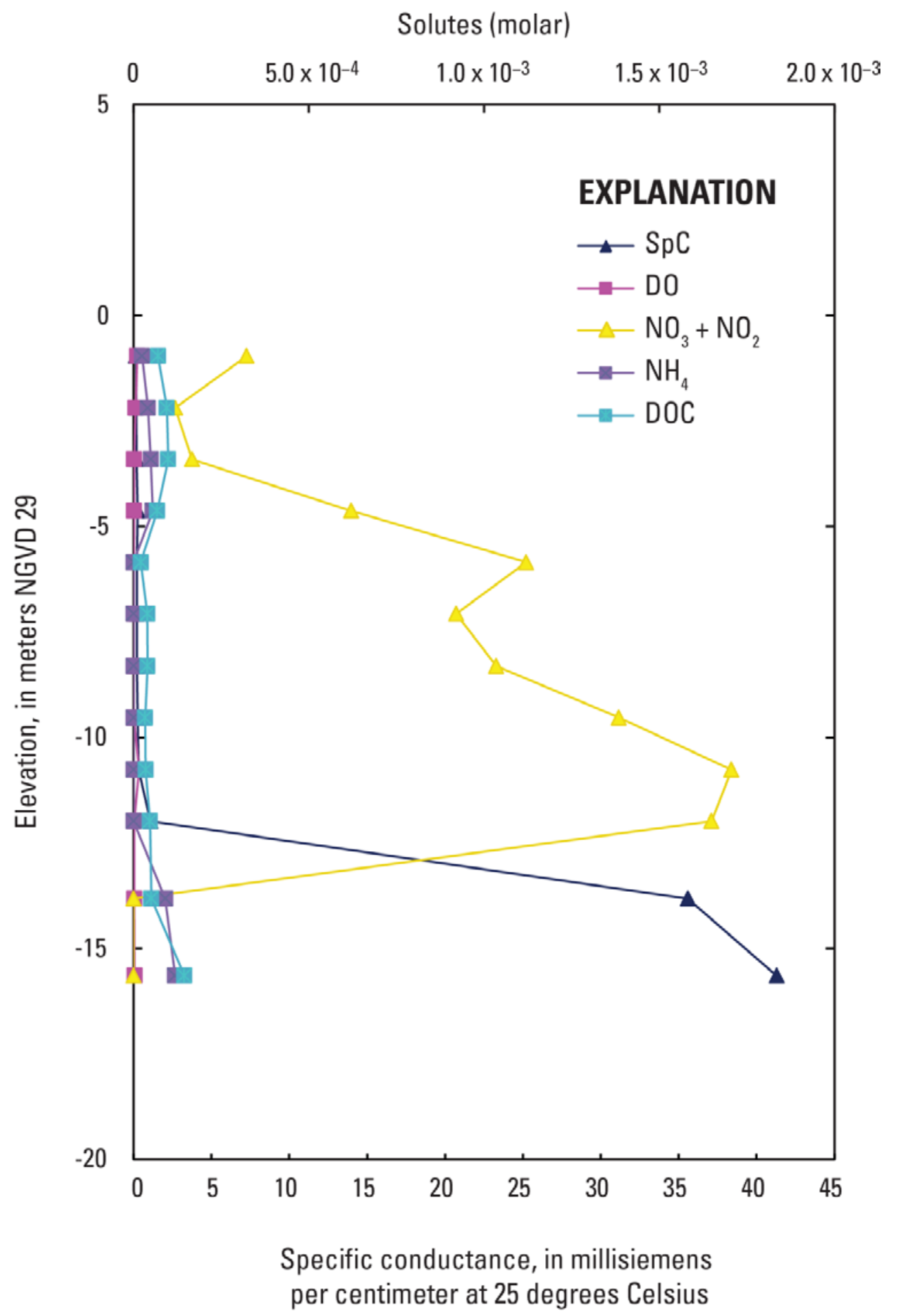

Figure 9. Solute concentrations in the aquifer at a peninsular coastal site Eel River, in Falmouth, Massachusetts (U.S. Geological Survey, unpub. data, 2014). DO, dissolved oxygen; DOC, dissolved organic carbon; $\mathrm{NO}_{3}+\mathrm{NO}_{2}$, nitrate plus nitrite; $\mathrm{NH}_{4}$, ammonium; NGVD 29, National Geodetic Vertical Datum of 1929; $\mathrm{SpC}$, specific conductance. 
This investigation adopted the aquifer chemical conditions of the Eel River site for the model's initial conditions; that is, substantial amounts of nitrate are assumed to be transported in the subsurface with low amounts of oxygen and low concentrations of ammonia. These chemical conditions are different from those measured at Waquoit Bay (Kroeger and Charette, 2008) or in Cape Cod subsurface investigations of large-scale wastewater plumes (DeSimone, 1992; Barbaro and others, 2013) but are used here because the measurements are from southern coastal Cape Cod. There are many variations possible for nearshore subsurface chemistry, but the assumed initial conditions are sufficient to demonstrate the model.

\section{Reactions}

The reactions that affect nitrogen transport and nitrogen loss primarily are redox reactions. Redox reactions used in this project follow those that characterize chemistry in other marine sediment systems (Berner and Berner, 1996; Spiteri and others, 2008). The reactions of dissolved organic matter degradation that pertain in the saltwater-flooded sediments occur in a sequence determined by the metabolic free energy yield of the reaction. A high energy-yielding process would dominate (run faster than) a low energy-yielding process until the reactants for the higher energy process have been consumed; then degradation switches over to the next most energetic process. Oxidation by dissolved oxygen is most favorable energetically, followed by oxidation by nitrate.

The sequence of reactions and kinetic formulations to accomplish the reactions follow those of Spiteri and others (2008; table 1). Values of the kinetic parameters used are also from Spiteri and others (2008; table 2). Regarding rates, only the faster $\mathrm{k}_{\text {fox } 2}$ kinetic parameter was used for dissolved organic matter decomposition because only dissolved organic matter of saltwater origin, which is labile, was included in the model. Freshwater dissolved organic matter is not labile (Spiteri and others, 2008). The value of $\mathrm{k}_{\text {nitri, }}$, the kinetic parameter used for nitrification, was within the range of values listed by Spiteri and others (2008) and was found to match well with the low concentrations of ammonia measured in the presence of oxygen at the Eel River site. The value of the kmo2 parameter used $\left(8 \times 10^{-6}\right.$ molar $\left.[\mathrm{M}]\right)$ was within the range of $6.3 \times 10^{-7}$ to $6.2 \times 10^{-5} \mathrm{M}$ listed by Spiteri and others (2008) and had the effect of allowing dissolved organic matter degradation at low dissolved oxygen concentrations. 
Table 1. Reactions and kinetic formulae included in the reactive transport model for southern coastal Cape Cod, Massachusetts.

[Reaction parameters are defined in table 2. Modified from Spiteri and others (2008). Eq. no., equation number; <, less than; $>$, greater than]

\begin{tabular}{|c|c|c|c|}
\hline $\begin{array}{l}\text { Eq. } \\
\text { no. }\end{array}$ & $\begin{array}{l}\text { Reaction name or } \\
\text { description }\end{array}$ & Reaction or reaction type & Kinetic formula or formula data source \\
\hline 1 & $\begin{array}{l}\text { Organic matter degradation } \\
\text { with oxygen electron } \\
\text { acceptor }\end{array}$ & $\begin{array}{l}\left.\left(\mathrm{CH}_{2} \mathrm{O}\right)_{106}\left(\mathrm{NH}_{3}\right)_{11}\left(\mathrm{H}_{3} \mathrm{PO}_{4}\right)\right]+106 \mathrm{O}_{2} \rightarrow \\
97 \mathrm{CO}_{2}+9 \mathrm{HCO}_{3}{ }^{-}+11 \mathrm{NH}_{4}{ }^{+}+\mathrm{HPO}_{4}{ }^{2-}+ \\
97 \mathrm{H}_{2} \mathrm{O}\end{array}$ & $\begin{array}{l}\text { If } \mathrm{O}_{2}>\mathrm{kmo}_{2} ; \text { rate }=\mathrm{k}_{\mathrm{fox}}\left[\left(\mathrm{CH}_{2} \mathrm{O}\right)_{106}\left(\mathrm{NH}_{3}\right)_{11}\right. \\
\left.\left(\mathrm{H}_{3} \mathrm{PO}_{4}\right)\right] \\
\text { If } \mathrm{O}_{2}<\mathrm{kmo} ; \text { rate }=\mathrm{k}_{\mathrm{fox}} \\
{\left[\left(\mathrm{CH}_{2} \mathrm{O}\right)_{106}\left(\mathrm{NH}_{3}\right)_{11}\left(\mathrm{H}_{3} \mathrm{PO}_{4}\right)\right]} \\
{\left[\mathrm{O}_{2}\right] /[\mathrm{kmo}]}\end{array}$ \\
\hline 2 & Nitrification & $\begin{array}{l}\mathrm{NH}_{4}^{+}+2 \mathrm{O}_{2}+2 \mathrm{HCO}_{3}^{-} \rightarrow \mathrm{NO}_{3}^{-}+2 \mathrm{CO}_{2}+ \\
\quad 3 \mathrm{H}_{2} \mathrm{O}\end{array}$ & Rate $=\mathrm{k}_{\text {nitri }}\left[\mathrm{NH}_{4+}\right]\left[\mathrm{O}_{2}\right]$ \\
\hline 3 & Denitrification & $\begin{array}{l}{\left[\left(\mathrm{CH}_{2} \mathrm{O}\right)_{106}\left(\mathrm{NH}_{3}\right)_{11}\left(\mathrm{H}_{3} \mathrm{PO}_{4}\right)\right]+84.8 \mathrm{NO}_{3} \rightarrow} \\
\quad 42.4 \mathrm{~N}_{2}+12.2 \mathrm{CO}_{2}+93.8 \mathrm{HCO}_{3}^{-}+11 \mathrm{NH}_{4}^{+} \\
\quad+\mathrm{HPO}_{4}^{2-}+54.6 \mathrm{H}_{2} \mathrm{O}\end{array}$ & 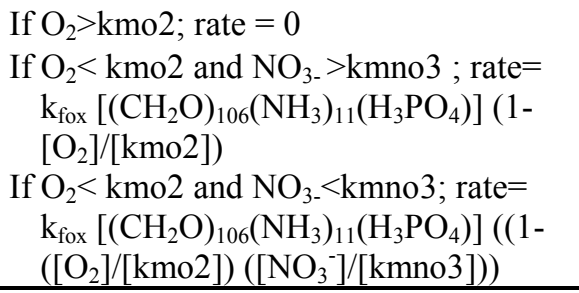 \\
\hline
\end{tabular}

Table 2. Values of kinetics parameters used for reactions in the reactive transport model for southern coastal Cape Cod, Massachusetts.

[Equations are listed in table 1. Modified from Spiteri and others (2008). DOM, dissolved organic matter; M, molar ; s, second]

\begin{tabular}{llll}
\hline Reaction parameter & \multicolumn{1}{c}{ Units } & \multicolumn{1}{c}{ Description } & Value \\
\hline $\mathrm{k}_{\mathrm{fox} 1}$ & $\mathrm{~s}^{-1}$ & Rate constant for decomposition of DOM & $3.0 \times 10^{-11 \mathrm{a}}$ \\
$\mathrm{k}_{\mathrm{fox2}}$ & $\mathrm{s}^{-1}$ & Alternate (faster) rate constant for decomposition of DOM & $3.0 \times 10^{-7} \mathrm{~b}$ \\
$\mathrm{k}_{\text {nitri }}$ & $\mathrm{M}^{-1} \mathrm{~s}^{-1}$ & Rate constant for nitrification & $4.8 \times 10^{-8 \mathrm{c}}$ \\
$\mathrm{kmo2}$ & $\mathrm{M}$ & Limiting concentration of oxygen & $8 \times 10^{-6} \mathrm{c}$ \\
$\mathrm{kmno3}$ & $\mathrm{M}$ & Limiting concentration of nitrate & $1 \times 10^{-6 \mathrm{c}}$ \\
\hline
\end{tabular}

${ }^{\mathrm{a}}$ Tromp and others, $1995 .{ }^{\mathrm{b}}$ Hunter and others, 1998. ${ }^{\mathrm{c}}$ Van Cappellen and Wang, 1995.

\section{Simulation With Mean-Tide Height}

The PHT3D model simulation of reaction with mean-tide height (step 3, "Model Development and Approach" section), in which the quasi-steady-state flow field from the SEAWAT simulation was used with reactions, was run forward for 700-day periods. Concentrations at the end of each 700-day period were used as the starting conditions for the subsequent simulation; simulations continued until quasi-steady-state concentrations of each constituent were reached.

\section{Initial and Boundary Conditions}

A fast approach to quasi-steady state in solutes results when initial concentrations and boundary concentrations are matched so that, after reaction, the reaction product concentrations of the infiltrating constituents equal the initial concentrations. For the present model, dissolved oxygen and dissolved organic matter infiltrate from offshore surface water to the subsurface through the sediment-water interface following flow (fig. 6). When dissolved oxygen and dissolved organic matter mix together, 
they result in a series of reactions. The initial reaction of these constituents in the subsurface is described by chemical equation 1 in table1. Ammonia is released from the dissolved organic matter and in turn reacts with oxygen according to chemical equation 2 in table 1, resulting in nitrate. As the oxygen is consumed by these reactions, the low-oxygen conditions necessary for denitrification develop, and nitrate is consumed by reaction with dissolved organic matter according to equation 3 in table 1 . To speed the approach to a quasi-steady state, we have estimated the concentrations that result after reaction and supplied these concentrations as initial conditions for zone 1 (table 3).

Table 3. Initial concentrations used in the aquifer and concentrations at model boundaries for an investigation of the subterranean estuary of the southern coast of Cape Cod, Massachusetts.

[Concentrations are in moles per liter, except for $\mathrm{pH}$ and pe, in standard units. GHB, general head boundary; DOM, dissolved organic matter; $\mathrm{NH}_{3}$, ammonia; $\mathrm{NO}_{3}$, nitrate; $\mathrm{O}_{2}$, oxygen]

\begin{tabular}{lcccc}
\hline \multirow{2}{*}{ Constituent } & \multirow{2}{*}{ Recharge } & GHB & \multicolumn{2}{c}{ Initial conditions } \\
\cline { 4 - 5 } & & & Zone 1 (salt) & Zone 2 (fresh) \\
\hline $\mathrm{DOM}$ & $1.0 \times 10^{-9}$ & $7.08 \times 10^{-6}$ & $5.30 \times 10^{-6}$ & $1.0 \times 10^{-9}$ \\
$\mathrm{NH}_{3}$ & $1.0 \times 10^{-9}$ & $1.0 \times 10^{-9}$ & $4.00 \times 10^{-6}$ & $1.0 \times 10^{-9}$ \\
$\mathrm{NO}_{3}$ & $5.1 \times 10^{-4}$ & $1.0 \times 10^{-9}$ & $1.0 \times 10^{-9}$ & $5.0 \times 10^{-4}$ \\
$\mathrm{O}_{2}$ & $1.0 \times 10^{-9}$ & $2.0 \times 10^{-4}$ & $1.0 \times 10^{-9}$ & $1.0 \times 10^{-9}$ \\
$\mathrm{pH}^{*}$ & 7 & 7 & 7 & 7 \\
$\mathrm{pe}^{*}$ & 4 & 4 & 4 & 4 \\
\hline
\end{tabular}

*Placeholder values; $\mathrm{pH}$ and pe do not affect the reaction kinetics used.

Zone 2, which is approximately the zone of freshwater (fig. 3), has initial concentrations of nitrate that would be in the recharge water from a septic-system source, (after dilution by recharge), zero dissolved oxygen $\left(1.0 \times 10^{-9} \mathrm{M}\right)$, and zero ammonia $\left(1.0 \times 10^{-9} \mathrm{M}\right)$. Values assumed for the simulation are recharge, $0.00167 \mathrm{~m} / \mathrm{d}$ with nitrogen concentration of $5.1 \times 10^{-4} \mathrm{M}$ or 7.12 milligrams of nitrogen per liter. Assumptions for nitrogen are housing density, 9.14 per hectare (measured by geographic information system in the area of Seacoast Shores, East Falmouth, Mass.; U.S. Geological Survey, 2015); households, 2.2 people per household (2010 census for East Falmouth; U.S. Census Bureau, 2012); nitrogen load, 5.95 pounds per person per year (Buzzards Bay National Estuarine Project, 2010); and loss from septic tank, 20 percent (Costa and others, 2002). Dissolved oxygen in zone 2 was set at zero $\left(1.0 \times 10^{-9} \mathrm{M}\right)$ because field investigation indicated that dissolved oxygen was gone from the aquifer under these conditions of housing density and thin unsaturated zone thickness (less than $6 \mathrm{~m}$; fig. 9).

\section{Results}

On the basis of solute changes, the simulation comes to quasi-steady state after nine to ten 700-day cycles (6,300-7,000 days; fig. 10). The resulting solute distributions were used as starting conditions for subsequent simulation of the tidal fluctuation effects in step 4. 

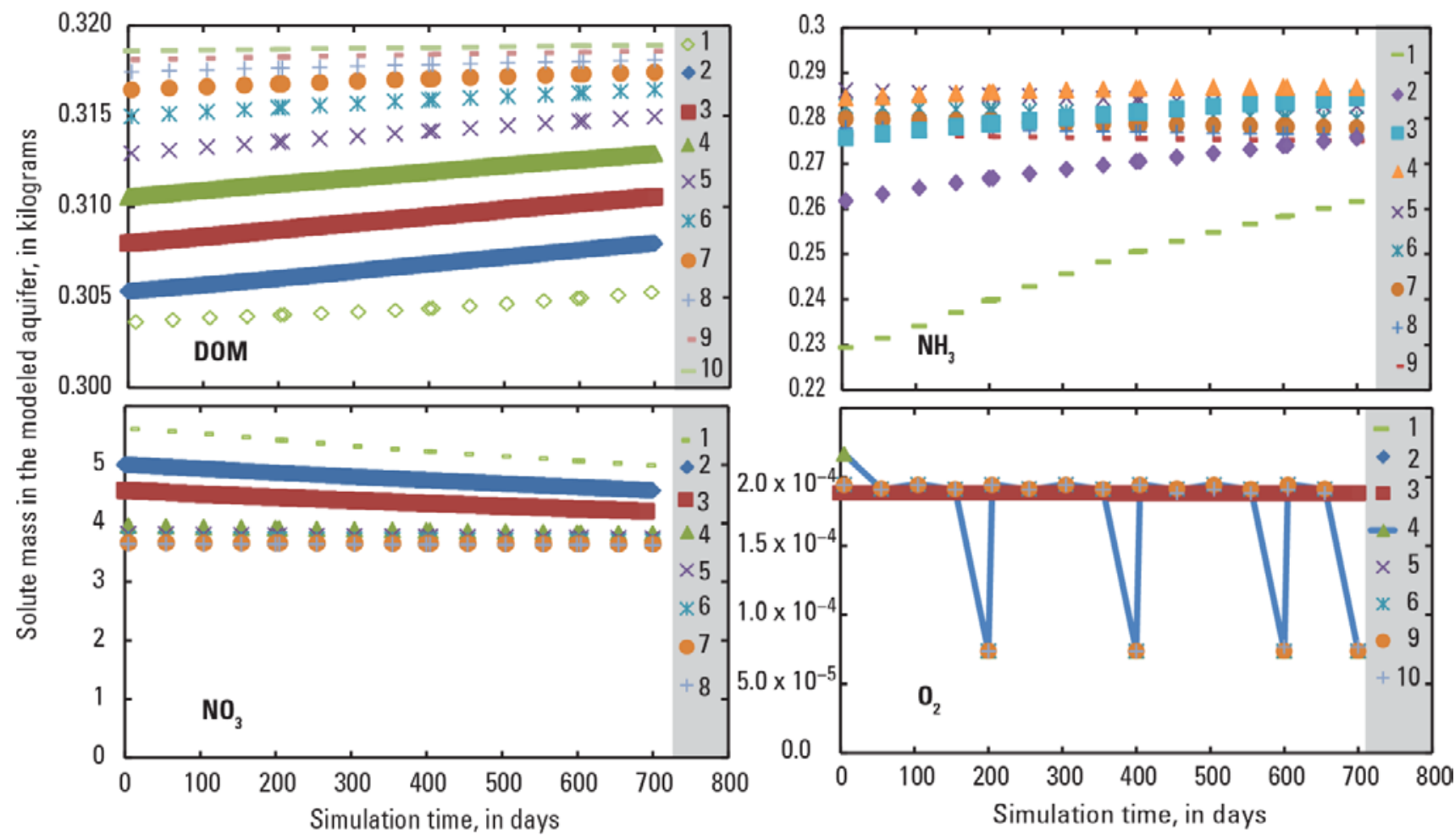

Figure 10. Solutes approach quasi-steady state of the aquifer for the PHT3D simulation in an investigation of the subterranean estuary of the southern coast of Cape Cod, Massachusetts. Numbers along the right side of the graphs refer to the sequence of model simulations. $\mathrm{DOM}$, dissolved organic matter; $\mathrm{NH}_{3}$, ammonia; $\mathrm{NO}_{3}$, nitrate; $\mathrm{O}_{2}$, oxygen.

The sequence of simulations shows that dissolved organic matter increases and nitrate decreases from the initial conditions. This is because, in the smoothing of the corner of zone 2 (fig. $3 \mathrm{~A}$ ), the area of saltwater, which contains dissolved organic matter, increases, and the area of freshwater, which has nitrate, decreases. The mass of ammonia first increases, then decreases. Ammonia forms at the interface between the saltwater and freshwater, reaches a quasi-steady state, and then decreases as the distance along the interface becomes rounded and thus shorter. Concentrations of dissolved oxygen fluctuate around a mean that is established even in the first 700-day model simulation. There is very little dissolved oxygen in the model. Dissolved oxygen is present only in water that infiltrates offshore, and it is quickly reacted with dissolved organic matter in the subsurface so that it is barely visible offshore (fig. 11).

Distribution of the concentrations after quasi-steady state was reached reflects the flow of groundwater and the reactivity of the chemical constituents involved (fig. 11). The flow field changed the distribution from the initial conditions into a more rounded distribution at the discharge end of the freshwater zone in a manner similar to that for saltwater. 


\section{EXPLANATION}

Constituent

concentration,

in moles per liter

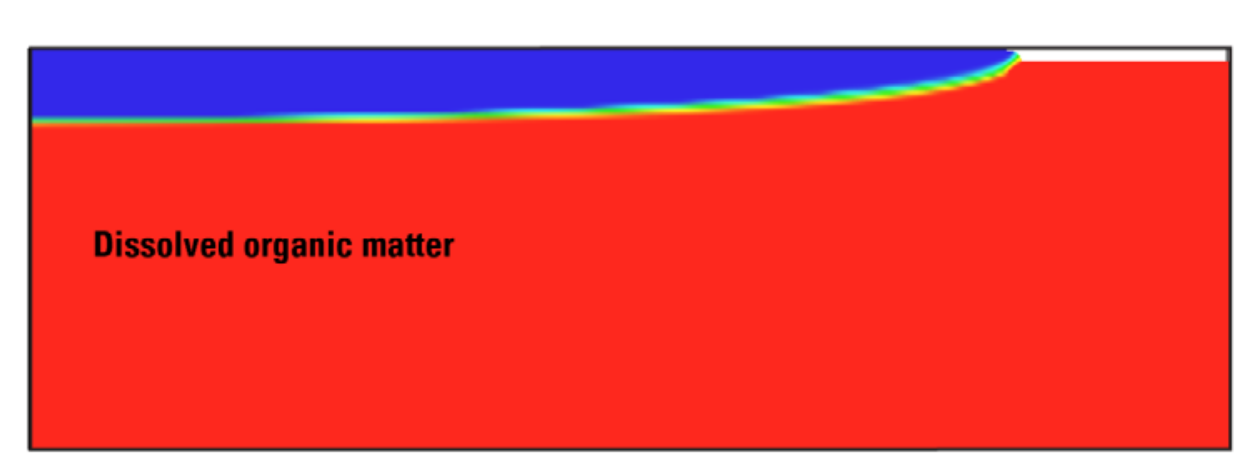

$5.00 \times 10^{-6}$

$3.75 \times 10^{-6}$

$2.50 \times 10^{-6}$

$1.25 \times 10^{-6}$

0.000

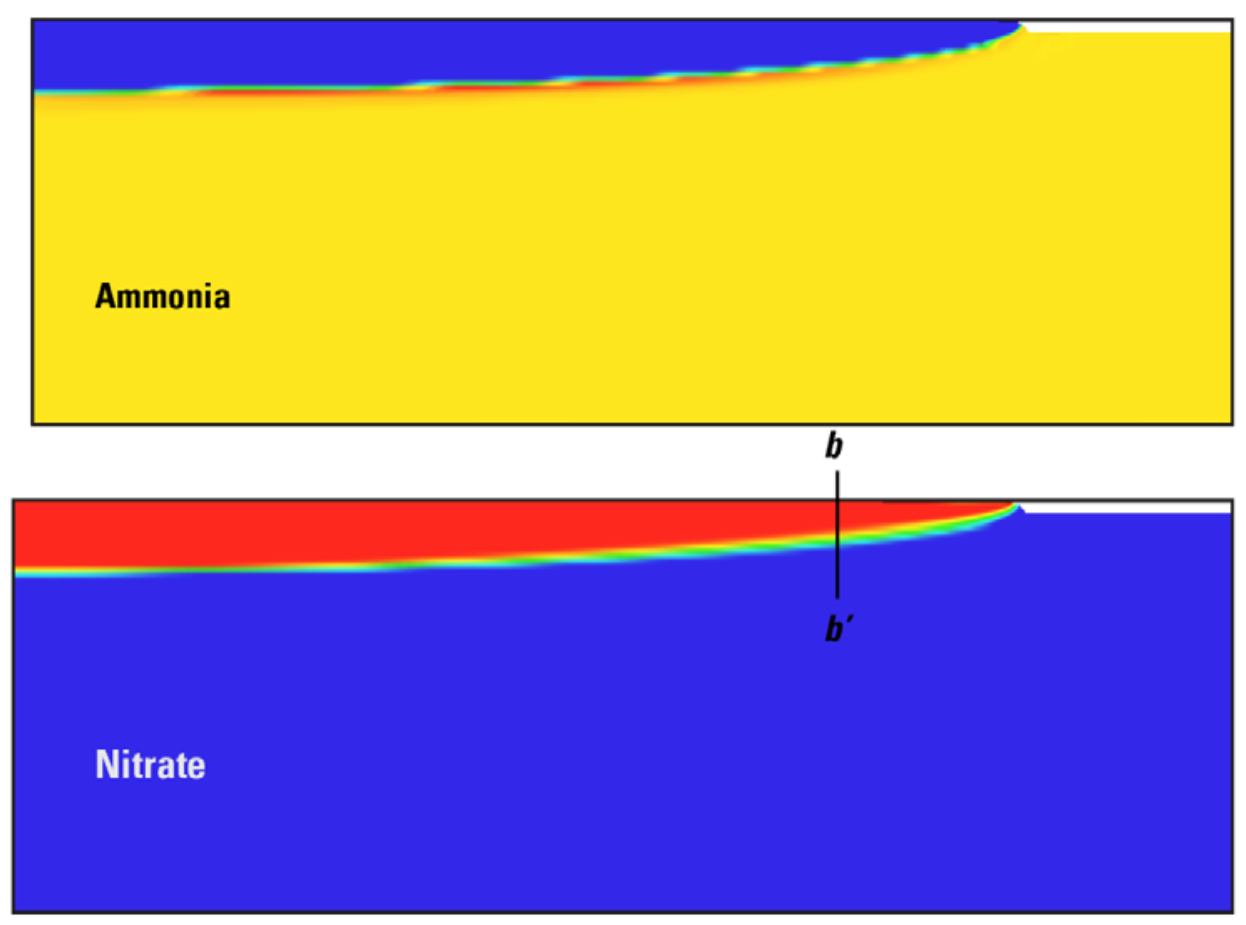

$2.50 \times 10^{-5}$

$2.00 \times 10^{-5}$

$1.50 \times 10^{-5}$

$1.00 \times 10^{-5}$

$5.00 \times 10^{-5}$

$5.00 \times 10^{-4}$

$3.75 \times 10^{-4}$

$2.50 \times 10^{-4}$

$1.25 \times 10^{-4}$

0.000

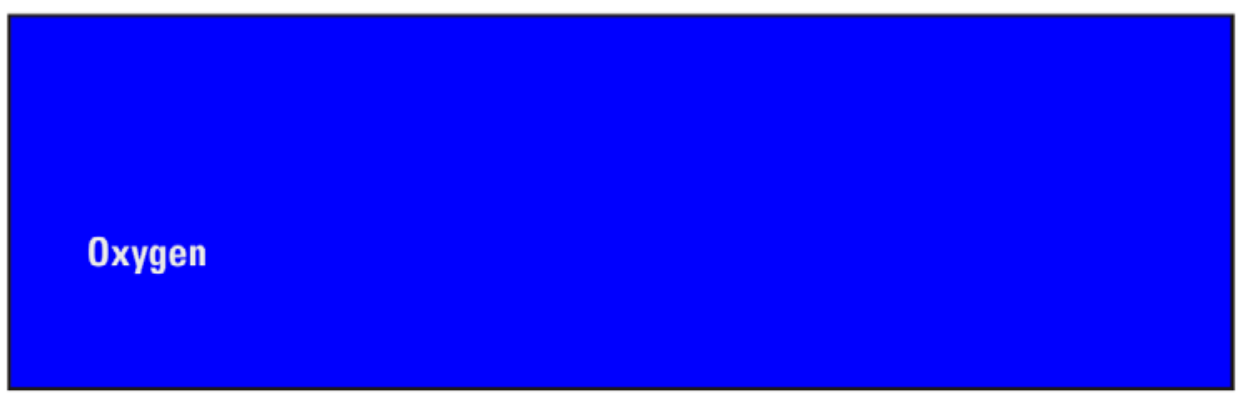

$2.0 \times 10^{-6}$

$1.5 \times 10^{-6}$

$1.0 \times 10^{-6}$

$5.0 \times 10^{-7}$

0.000

Figure 11. Distribution of solutes in the mean tide PHT3D simulation for the subterranean estuary in southern coastal Cape Cod, Massachusetts, after aquifer mass approaches quasi-steady-state conditions at 6,300 days. Cross section $b-b^{\prime}$ refers to the concentration profiles in figure 12. Color bar concentrations are in molar units. 
More detail in the area of the freshwater/saltwater interface can be seen in constituent concentration profiles (fig. 12). The vertical gradient in the sea-salt profile reflects vertical mixing between the freshwater and saltwater without any effect of reaction.

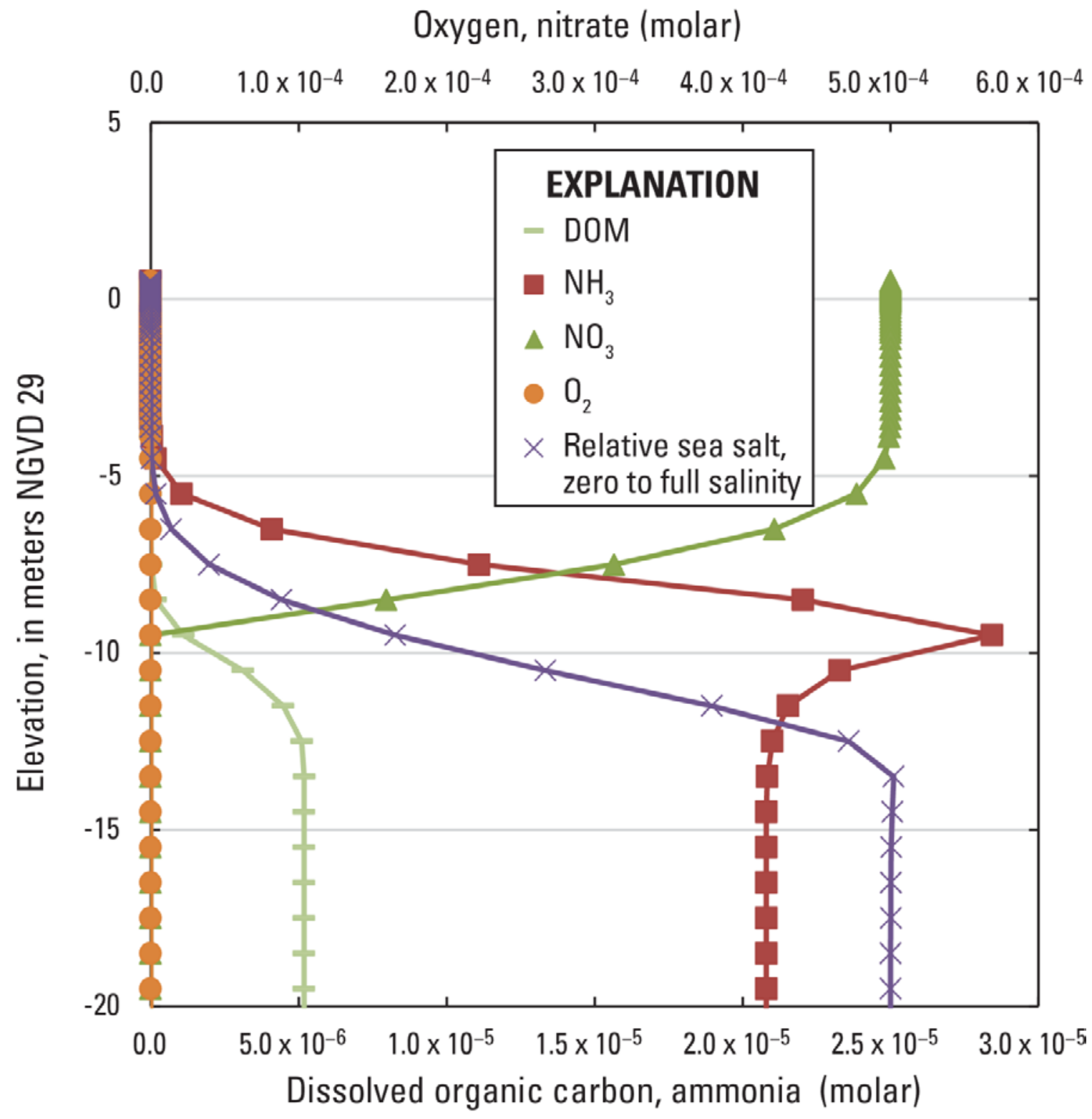

Figure 12. Results from the mean-tide PHT3D simulation showing constituent concentration profiles after 6,300 days of simulation across the freshwater/saltwater interface in an investigation of the subterranean estuary of the southern coast of Cape Cod, Massachusetts. Location is section $b-b$ ' of figure 11. DOM, dissolved organic matter; $\mathrm{NH}_{3}$, ammonia; $\mathrm{NO}_{3}$, nitrate; $\mathrm{O}_{2}$, oxygen. 
Reactive constituents are subject to the same mixing as that between freshwater and saltwater but have altered vertical gradients in their profiles because of reaction. Dissolved organic matter in the saltwater zone reacts with nitrate in the freshwater zone so that these two species exhibit steep gradients across the freshwater/saltwater interface (fig. 12). Ammonia occurs in the saltwater zone because of release from dissolved organic matter during oxidation by dissolved oxygen. (Dissolved organic matter and dissolved oxygen infiltrate offshore through the GHB boundaries.) At the freshwater/saltwater interface, additional ammonia is produced as the organic matter reacts with nitrate in the freshwater zone.

Although the concentration of dissolved organic matter appears to be two orders of magnitude lower than that of other reactants (fig. 12), the number of carbon atoms per molecule (106; table 1) means that similar atom-to-atom abundance exists among the reactants.

The reaction of dissolved organic matter and nitrate at the freshwater/saltwater interface is denitrification, the conversion of nitrate to nitrogen gas, which is inert in the context of eutrophication. Denitrification can be assessed from the .out file of the PHT3D model. This file lists the cumulative flux in recharge and the cumulative amount of reaction in and out for each solute simulated. For the meantide simulation, the fraction of nitrate nitrogen that comes into the aquifer (from recharge, mostly) that is denitrified is 15 percent. The profiles in figure 12 show that the reactants do not overlap. The reaction is fast by comparison with the rate at which the reactants are mixed together. Thus, the mixing rate determines the reaction rate.

\section{Fluctuating Tide PHT3D Simulation} section).

Simulation of reactions with a fluctuating tide is step 4 ("Model Development and Approach"

\section{Structure}

The model grid, bottom and side boundaries, recharge amount, and fluctuating head (and GHB and DRN cells) associated with tides were taken from the transient SEAWAT model. Recharge and GHB solute concentrations were the same as for the mean-tide transport simulation (table 3). Initial chemical conditions were the ending conditions from the mean-tide solute transport simulations at 6,300 days (fig. 11). The flow field used was from the fluctuating-tide SEAWAT model after salt steady state had been reached at 2,923 days.

\section{Concentration Results}

Repeated 730-day simulations were used. The output from one simulation was used as the input to the next until quasi-steady state was established for each constituent (fig. 13). 

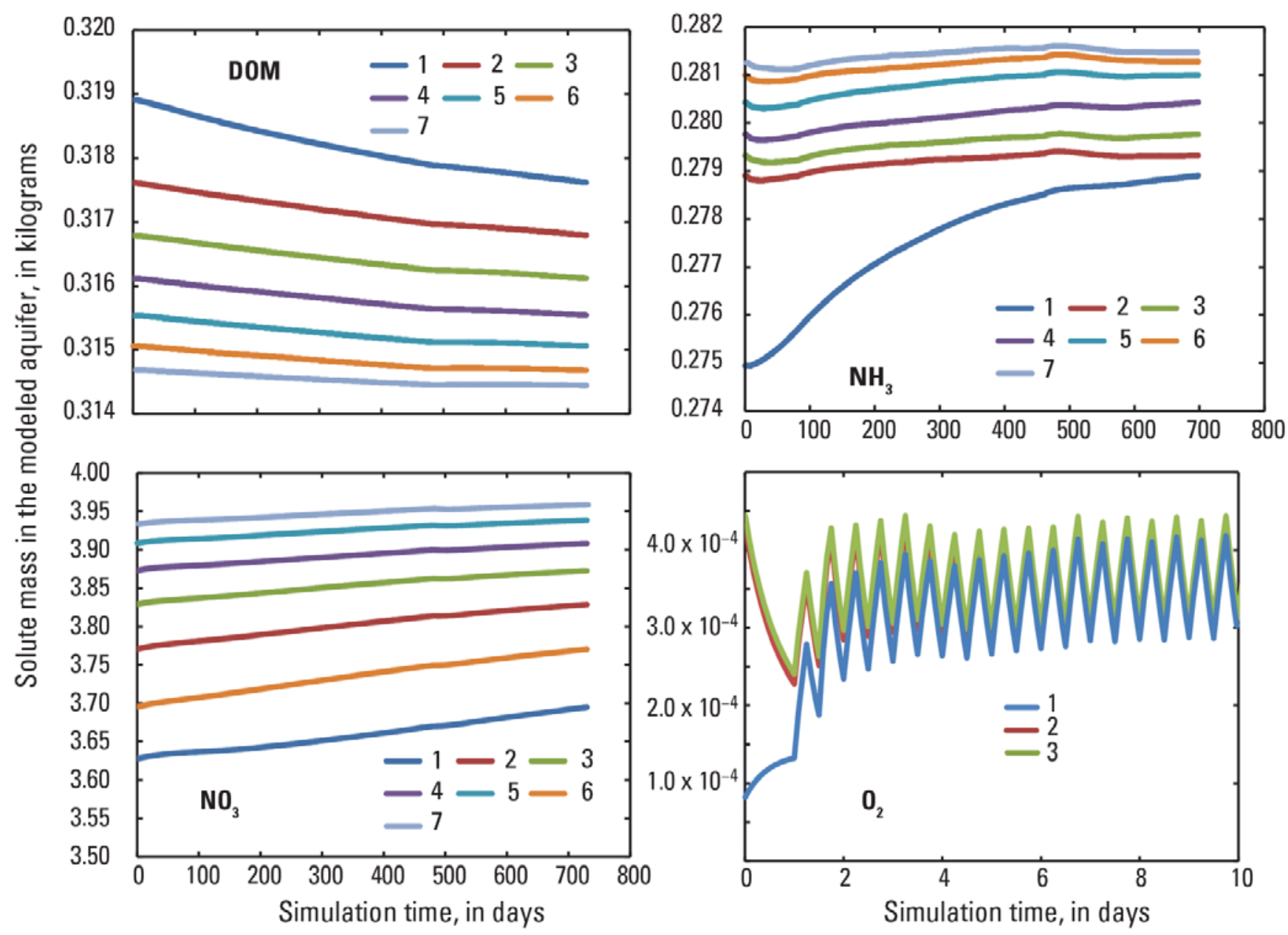

Figure 13. Results from the uncalibrated fluctuating-tide PHT3D model in an investigation of the subterranean estuary of the southern coast of Cape Cod, Massachusetts, showing the approach of solutes to equilibrium mass content of the aquifer. Each simulation is 730 days. Numbers in the legends refer to sequence of model simulations. DOM, dissolved organic matter; $\mathrm{NH}_{3}$, ammonia; $\mathrm{NO}_{3}$, nitrate; $\mathrm{O}_{2}$, oxygen.

The tidal fluctuation associated with the transient conditions was expected to alter the mean-tide model solute distributions only slightly, mostly in the region of discharge where the effects of tides are strongest. However, the results indicated that infiltration occurred at a faster rate in addition to greater mixing in the discharge zone. This is most apparent in the dissolved oxygen distribution (fig. 14). By comparison with dissolved oxygen in the mean-tide model (fig. 11), there is a greater concentration of dissolved oxygen in the tidal/discharge zone, as well as along the surface of the entire offshore sediments. 
EXPLANATION

Oxygen concentration, in moles per liter
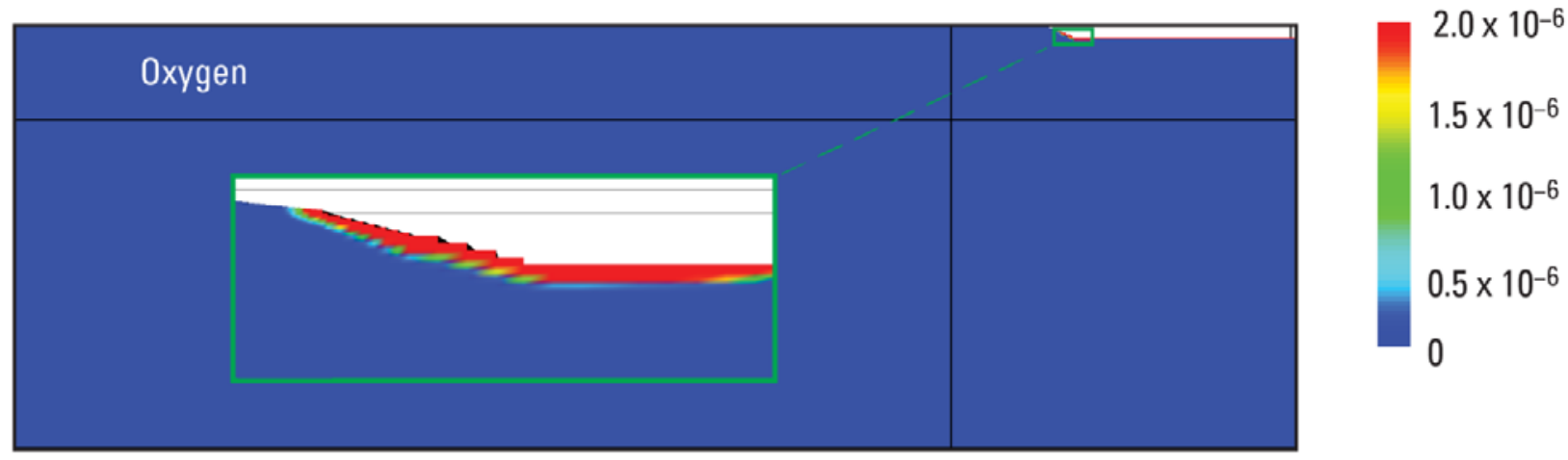

Figure 14. Distribution of oxygen in the uncalibrated fluctuating-tide PHT3D simulation in an investigation of the subterranean estuary of the southern coast of Cape Cod, Massachusetts, after quasi-steady state in solutes had been reached, with detail shown for the shore area.

The amount of nitrogen that is denitrified as a fraction of that recharged is 20 percent. Thus, a small tidal amplitude of $0.2 \mathrm{~m}$ increased the denitrification rate as compared with the mean-tide model. With tidal fluctuation, reaction can take place at the sediment/water interface, as well as in the interface with the deep salt cell.

\section{Limitations of Analysis}

The general nature of the model presented in this report is that of a generic 2D cross-sectional model that is considered representative of the subterranean estuary near a saline pond on Cape Cod, and as such, no model calibration was done because no measured flow or aquifer-characteristics data were available to which a calibration could be made.

The model would benefit from an investigation of the sensitivity of model results, such as nitrogen reaction and seawater infiltration, to model parameters. The model included fine grid spacing near the top surface because that is an area where flow and mixing could affect groundwater discharge nitrogen reactivity, but the deep saltwater wedge interface is a second area of potential nitrogen reaction and the zone where the rate of density driven seawater recirculation is determined. Thus, some future testing of the model grid could involve the following:

- Varying column widths along shoreline cells and layers. Cell size may influence the effect of tidal fluctuation on the groundwater flow directions at the freshwater/saltwater interface and the spread or thickness of the interface zone.

- Varying layer thickness in the zone of the deep saltwater wedge. Mixing in this zone controls reaction rate and seawater infiltration rate.

- Varying the landward extent and depth (fewer layers not extending to bedrock) to make the model smaller. Although this would alter the physical-based dimensions of the modeled area, the grid elements saved could help with simulation times that would be extended if the grid were refined as in the previous items in this list. 
Other aspects for sensitivity testing include the following:

- Varying hydraulic conductivity with depth on the basis of measured sediment characteristics, especially soft sediment that could be probed offshore.

- Varying the conductance of GHB and DRN cells because of possible effects on the distance to which freshwater flows under the ocean bottom.

- Varying the tidal amplitude. Tidal fluctuation of $0.2 \mathrm{~m}$ may not be enough head difference to cause salt to move into the subsurface.

As shown, the rate of nitrogen attenuation is determined largely by the mixing of water that contains the two reactants dissolved organic matter and nitrate. To an extent, if mixing increases, the amount of nitrogen reacted will increase. Mixing in the subsurface, according to measurement, occurs at very slow rates (Garabedian and others, 1991). But in simulations, mixing can be controlled by an artifact of computing called numerical dispersion.

Numerical dispersion is approximated by the following equation:

$$
D=\frac{\Delta X}{2}+\frac{V \Delta T}{2}
$$

where
$D \quad$ is the numerical dispersivity,
$\Delta X \quad$ is the grid spacing in the direction of flow,
$\Delta T \quad$ is the time step, and
$V \quad$ is the velocity (Parkhurst and others, 2003).

The numerical dispersivity in the vertical direction of flow is approximately $\mathrm{D}=1 / 2+0 \times 0.01 / 2$ $\approx 0.5 \mathrm{~m}$.

Vertical spacing of the grid is $1.0 \mathrm{~m}$ in the region of the deep saltwater/freshwater interface. Vertical velocity is low; here, zero was assumed as a lower bound. The second term in the dispersivity equation goes to zero when the velocity is low, so that grid spacing becomes the only factor that determines dispersivity. The calculated numerical dispersion rate of $0.5 \mathrm{~m}$ is about 330 times greater than the $0.0015-\mathrm{m}$ vertical dispersivity measured by Garabedian and others (1991) in similar outwash deposits on Cape Cod.

Numerical dispersion, which is so much greater than measured dispersion, may be a problem for this model. Kroeger and Charette (2008) found that mixing at the deep interface controls the rate of chemical reaction there. That means that the rate limiting process is bringing together reactants by mixing and that once the reactants are together, the rate of chemical (or microbially mediated) reaction proceeds relatively quickly. Similarly, the chemical reaction rates used in this model (table 2) are fast enough not to be limiting in comparison to the rate of mixing reactants together. So the artificially high rate of mixing in the model caused by numerical dispersion will cause the simulation of the amount of nitrogen reacted to be greater than would occur at the mixing rate measured by Garabedian and others (1991).

Dispersion also affects the density driven convection across the saltwater wedge, which in turn causes the infiltration of saltwater offshore (Smith, 2004). Thus, artificially high mixing at the saltwater wedge interface would increase the rate of infiltration of seawater. For example, the magnitude of this effect for a 2D model similar to the model described here, and with a transverse dispersivity of $0.5 \mathrm{~m}$, was a factor of a 1.3 increase in seawater circulation as cell size was changed from $0.5 \mathrm{~m}$ to $5 \mathrm{~m}$ (Smith, 2004). 


\section{Summary and Conclusions}

A two-dimensional model that includes density, reactivity, and tidal fluctuation for the subterranean estuary was constructed in a study conducted by the U.S. Geological Survey, in cooperation with the U.S. Environmental Protection Agency, to simulate ranges of nitrogen attenuation that are possible given literature values of nitrogen reactivity and groundwater flow and tidal-fluctuation rates representative of the south shore of Falmouth, Massachusetts, on Cape Cod. Because density and tidal fluctuation affect flow in the subterranean estuary and because nitrogen attenuation chemistry is complex, a series of SEAWAT-2000 (SEAWAT) and PHT3D simulations were required.

1. A mean tide SEAWAT simulation was run until quasi-steady state of salt content was reached.

2. The quasi-steady-state salt content of 1 was used as an initial condition in a fluctuating-tide SEAWAT simulation and run until quasi-steady-state salt content was reached.

3. The flow field of simulation 1 was used in a mean-tide PHT3D simulation to assess nitrogen attenuation; the simulation was run until quasi-steady-state solute content was reached.

4. The flow field of simulation 2 was used with the quasi-steady-state solute content of simulation 3 as initial conditions in a fluctuating tide PHT3D simulation, which was run until quasi-steadystate solute content was reached.

Results of the mean tide PHT3D simulation indicate that 15 percent of the recharged nitrogen was denitrified at the deep saltwater wedge. In the subsequent simulation with fluctuating tide, the amount of recharged nitrogen that was denitrified increased to 20 percent. Also, by comparison with the mean-tide simulation, the tidal-fluctuation simulation changed the location of freshwater discharge from the aquifer from the area of mean high tide to that of mean low tide.

Numerical dispersion may distort the rates of reaction and the rate of infiltration that occurs on the ocean side. More investigation of the effect of numerical dispersion is needed for simulations that are calibrated to field observations.

The modeling approach enables the simulation of time- and mixing-dependent reactions in a flow field that is affected by variable density from fresh and saltwater mixing, such as occurs in the subterranean estuary. When data are available, calibrated model results could indicate what fraction of nitrogen moving from sources on the land to discharge offshore is attenuated. Such losses are important to calculate for coastal communities attempting to comply with assessed total maximum daily loads for nitrogen.

\section{References Cited}

Abarca, Elena, Karam, Hanan, Hemond, H.F., and Harvey, C.F., 2013, Transient groundwater dynamics in a coastal aquifer-The effects of tides, the lunar cycle, and the beach profile: Water Resources Research, v. 49, no. 5, p. 2473-2488.

Anwar, N., Robinson, C., Barry, D.A., 2014, Influence of tides and wave on the fate of nutrients in a nearshore aquifer: numerical simulations: Advances in Water Resources, v. 73, p. 203-213.

Barbaro, J.R., Walter, D.A., and LeBlanc, D.R., 2013, Transport of nitrogen in a treated-wastewater plume to coastal discharge areas, Ashumet Valley, Cape Cod, Massachusetts: U.S. Geological Survey Scientific Investigations Report 2013-5061, 37 p., http://pubs.usgs.gov/sir/2013/5061/.

Barlow, P.M., 2003, Ground water in freshwater/saltwater environments of the Atlantic coast: U.S. Geological Survey Circular 1262, 113 p.

Belaval, Marcel, Lane, J.W., Jr., Lesmes, D.P., and Kineke, G.C., 2003, Continuous-resistivity profiling for coastal groundwater investigations - Three case studies, in Proceedings of the Symposium on the 
Application of Geophysics to Engineering and Environmental Problems (SAGEEP), San Antonio, Texas, April 6-10, 2003: Environmental and Engineering Geophysical Society, CD-ROM, 14 p.

Berner, E.K., and Berner, R.K., 1996, Global environment-Water, air and geochemical cycles: New Jersey, Prentice Hall, 488 p.

Buzzards Bay National Estuarine Project, 2010, Nitrogen loading model assumptions: Buzzards Bay National Estuarine Project Web page, accessed November 15, 2010, at http://BB_MEP_Nitrogen Loading Model Assumptions.mht.

Colman, J.A., Masterson, J.P., Pabich, W.J., and Walter, D.A., 2004, Effects of aquifer travel time on nitrogen transport to a coastal embayment: Ground Water-Oceans Issue, v. 42, no. 7, p. 1069-1078.

Costa, J.E., Heufelder, George, Foss, Sean, Milham, N.P., and Howes, Brian, 2002, Nitrogen removal efficiencies of three alternative septic system technologies and a conventional septic system:

Environment Cape Cod, v. 5, no. 1, p. 15-24, accessed September 2011, at http://www.buzzardsbay.org/etistuff/results/costaenvccarticle2.pdf.

Cross, V.A., Bratton, J.F., Crusius, John, Colman, J.A., and McCobb, T.D., 2008, Submarine hydrological data from Cape Cod National Seashore: U.S. Geological Survey Open-File Report 20061169, http://woodshole.er.usgs.gov/pubs/of2006-1169.

Crusius, J., Koopmans, D., Bratton, J.F., Charette, M.A., Kroeger, K.D., Henderson, P. Ryckman, L., Halloran, K., and Colman, J.A., 2005, Submarine groundwater discharge to a small estuary estimated from radon and salinity measurements and a box model: Biogeosciences, v. 2, p. 141-157.

DeSimone, L.A., Barlow, P.M., and Howes, B.L., 1996, A nitrogen rich septage-effluent plume in a glacial aquifer, February 1990 through December 1992: U.S. Geological Survey Water-Supply Paper 2456, 89 p.

Fairchild, G.M., Lane, J.W., Jr., Voytek, E.B., and LeBlanc, D.R., 2013, Bedrock topography of western Cape Cod, Massachusetts, based on bedrock altitudes from geologic borings and analysis of ambient seismic noise by the horizontal-to-vertical spectral-ratio method: U.S. Geological Survey Scientific Investigations Map 3233, 1 sheet plus 17-p. pamphlet, http://pubs.usgs.gov/sim/3233/.

Fetter, C.W., 1994, Applied hydrology (3d ed.): Upper Saddle River, N.J., Prentice Hall, 681 p.

Garabedian, S.P., LeBlanc, D.R., Gelhar, L.W., and Celia, M.A., 1991, Large-scale natural-gradient tracer test in sand and gravel, Cape Cod, Massachusetts - 2, Analysis of spatial moments for a nonreactive tracer: Water Resources Research, v. 27, no. 5, p. 911-924.

Guo, Weixing, and Langevin, C.D., 2002, User's guide to SEAWAT-A computer program for simulation of three-dimensional variable-density ground-water flow: U.S. Geological Survey Techniques of Water-Resources Investigations, book 6, chap. A7, 77 p.

Harbaugh, A.W., Banta, E.R., Hill, M.C., and McDonald, M.G., 2000, MODFLOW-2000, the U.S Geological Survey modular ground-water model-User guide to modularization concepts and the ground-water flow process: U.S. Geological Survey Open-File Report 00-92, 121 p.

Harbaugh, A.W., and McDonald, M.G., 1996, User's documentation for MODFLOW-96, an update to the U.S. Geological Survey modular finite-difference ground-water flow model: U.S. Geological Survey Open-File Report 96-485, 56 p.

Hunter, K.S., Wang, Yifeng, and Van Cappellen, Phiippe, 1998, Kinetic modeling of microbially-driven redox chemistry of subsurface environments - Coupling transport, microbial metabolism and geochemistry: Journal of Hydrology, v. 209, nos. 1-4, p. 53-80.

Kroeger, K.D., and Charette, M.A., 2008, Nitrogen biogeochemistry of submarine groundwater discharge: Limnology and Oceanography, v. 53, no. 3, p. 1025-1039.

Langevin, C.D., Shoemaker, W.B., and Guo, Weixing, 2003, MODFLOW-2000, the U.S. Geological Survey modular ground-water model-Documentation of the SEAWAT-2000 version with variable- 
density flow process (VDF) and the integrated MT3DMS transport process (IMT): U.S. Geological Survey Open-File Report 03-426, 43 p.

Massachusetts Department of Environmental Protection, 2003, The Massachusetts estuaries projectEmbayment restoration and guidance for implementation strategies: Boston, Massachusetts Department of Environmental Protection, 40 p., accessed September 2011, at http://www.mass.gov/eea/docs/dep/water/resources/a-thru-m/mepmain.pdf.

Massachusetts Estuaries Project, 2011, Welcome to the Massachusetts estuaries project: Boston, Massachusetts Department of Environmental Protection, accessed September 2011, at http://www.oceanscience.net/estuaries/.

McCobb, T.D., and LeBlanc, D.R., 2002, Detection of fresh ground water and a contaminant plume beneath Red Brook Harbor, Cape Cod, Massachusetts, 2000: U.S. Geological Survey WaterResources Investigations Report 02-4166, 36 p.

Michael, H.A., Lubetsky, J.S., and Harvey, C.F., 2003, Characterizing submarine groundwater discharge-A seepage meter study in Waquoit Bay, Massachusetts: Geophysical Research Letters, v. 30 , no. 6 , p. $1-4$.

Michael, H.A., Mulligan, A.E., and Harvey, C.F., 2005, Seasonal oscillations in water exchange between aquifers and the coastal ocean: Nature, v. 436, no.7054, p. 1145-1148.

Mulligan, A.E., Langevin, Christian, and Post, V.E.A., 2011, Tidal boundary conditions in SEAWAT: Ground Water, v. 49, p. 866-879.

Parkhurst, D.L., and Appelo, C.A.J., 1999, User's guide to PHREEQC (Version 2)—A computer program for speciation, batch-reaction, one-dimensional transport, and inverse geochemical modeling: U.S. Geological Survey Water-Resources Investigations Report 99-4259, 312 p.

Parkhurst, D.L., Stollenwerk, K.G., and Colman, J.A., 2003, Reactive transport simulation of phosphorus in the sewage plume at the Massachusetts military reservation, Cape Cod, Massachusetts: U.S. Geological Survey Water-Resources Investigations Report 03-4017, 33 p.

Prommer, Henning, and Post, Vincent, 2010, PHT3D — A reactive multicomponent transport model for saturated porous media: PHT3D Web site, accessed September 2011, at http://www.pht3d.org/.

Repert, D.A., Barber, L.B., Hess, K.M., Keefe, S.H., Kent, D.B., LeBlanc, D.R., and Smith, R.L., 2006, Long-term natural attenuation of carbon and nitrogen within a groundwater plume after removal of the treated wastewater source: Environmental Science and Technology, v. 40, no. 4, p. 1154-1162.

Robertson, W.D., Moore, T.A,. Spoelstra, J., Li, L., Elgood, R.J., Clark, I.D., Schiff, S.L., Aravena, R., and Neufeld, J.D., 2011, Natural attenuation of septic system nitrogen by anammox: Ground Water, v. 50, no. 4, p. 541-553.

Savoie, J.G., and LeBlanc, D.R., 1998, Water-quality data and methods of analysis for samples collected near a plume of sewage-contaminated ground water, Ashumet Valley, Cape Cod, Massachusetts, 1993-94: U.S. Geological Survey Water-Resources Investigations Report 97-4269, $208 \mathrm{p}$.

Smith, A.J., 2004, Mixed convection and density-dependent seawater circulation in coastal aquifers: Water Resources Research, v. 40, no. 8, W08309, 16 p.

Smith, R.L., Böhlke, J.K., Garabedian, S.P., Révész, K.M., and Yoshinari, Tadashi, 2004, Assessing denitrification in groundwater using natural gradient tracer test with $15 \mathrm{~N}$ - In situ measurement of a sequential multistep reaction: Water Resources Research, v. 40, no. 7, W07101, 17 p.

Spiteri, Claudette, Slomp, C.P., Charette, M.A., Tuncay, Kagan, and Meile, Christof, 2008, Flow and nutrient dynamics in a subterranean estuary (Waquoit Bay, MA, USA) - Field data and reactive transport modeling: Geochimica et Cosmochimica Acta, v. 72, no. 14, p. 3398-3412. 
Tromp, T.K., Van Cappellen, P., and Key, R.M., 1995, A global model for the early diagenesis of organic carbon and organic phosphorous in marine sediments: Geochimica et Cosmochimica Acta, v. 59 , no. 7 , p. $1259-1284$.

U.S. Census Bureau, 2012, accessed through MassGIS, http://www.mass.gov/anf/research-and-tech/itserv-and-support/application-serv/office-of-geographic-informationmassgis/datalayers/census2010.html

U.S. Geological Survey, 2015, USGS color ortho imagery (2013/2014): Massachusetts Office of Geographic Information data, accessed April 24, 2015, at http://www.mass.gov/anf/research-andtech/it-serv-and-support/application-serv/office-of-geographic-informationmassgis/datalayers/layerlist.html.

Van Cappellen, Philippe, and Wang, Yifeng, 1995, Metal cycling in surface sediments-Modeling the interplay of transport and reaction, chap. 2 of Allen, H.E., ed., Metal contaminated aquatic sediments: Chelsea, Mich., Ann Arbor Press, p. 21-64.

Walter, D.A., 2008, Use of numerical models to simulate transport of sewage-derived nitrate in a coastal aquifer, central and western Cape Cod, Massachusetts: U.S. Geological Survey Scientific Investigations Report 2007-5259, $41 \mathrm{p}$.

Walter, D.A., and Whealan, A.T., 2005, Simulated water sources and effects of pumping on surface and ground water, Sagamore and Monomoy flow lenses, Cape Cod, Massachusetts: U.S. Geological Survey Scientific Investigations Report 2004-5181, 85 p. 
For more information concerning this report, contact: Director, New England Water Science Center

U.S. Geological Survey

10 Bearfoot Road

Northborough, MA 01532

dc_nweng@usgs.gov

or visit our Web site at:

http://ma.water.usgs.gov

http://ri.water.usgs.gov

Publishing support by:

The Pembroke Publishing Service Center. 
